\title{
Carbon-11 and Fluorine-18 Labeled Amino Acid Tracers for Positron Emission Tomography Imaging of Tumors
}

\author{
Aixia Sun ${ }^{1+}$, Xiang Liu ${ }^{2+}$ and Ganghua Tang ${ }^{1 *}$ \\ 1 Guangdong Engineering Research Center for Translational Application of Medical Radiopharmaceuticals and Department of \\ Nuclear Medicine, The First Affiliated Hospital, Sun Yat-sen University, Guangzhou, China, ${ }^{2}$ Department of Anesthesiology, \\ The Sixth Affiliated Hospital, Sun Yat-sen University, Guangzhou, China
}

OPEN ACCESS

Edited by:

Steven Liang,

Massachusetts General Hospital, Harvard Medical School,

United States

Reviewed by:

Benjamin Rotstein

University of Ottawa, Canada

Adriano Mollica,

Dipartimento di Farmacia, Universitá

d'Annunzio, Italy

Aleksandra Pekosak,

VU University Medical Center,

Netherlands

*Correspondence:

Ganghua Tang

gtang0224@126.com

${ }^{\dagger}$ These authors have contributed equally to this work.

Specialty section:

This article was submitted to

Medicinal and Pharmaceutical

Chemistry,

a section of the journal

Frontiers in Chemistry

Received: 04 August 2017 Accepted: 12 December 2017

Published: 15 January 2018

Citation:

Sun A, Liu X and Tang G (2018) Carbon-11 and Fluorine-18 Labeled

Amino Acid Tracers for Positron

Emission Tomography Imaging of

Tumors. Front. Chem. 5:124.

doi: 10.3389/fchem.2017.00124
Tumor cells have an increased nutritional demand for amino acids (AAs) to satisfy their rapid proliferation. Positron-emitting nuclide labeled AAs are interesting probes and are of great importance for imaging tumors using positron emission tomography (PET). Carbon-11 and fluorine-18 labeled AAs include the $\left[1-{ }^{11} \mathrm{C}\right] \mathrm{AAs}$, labeling alpha-C- AAs, the branched-chain of AAs and N-substituted carbon-11 labeled AAs. These tracers target protein synthesis or amino acid (AA) transport, and their uptake mechanism mainly involves AA transport. AA PET tracers have been widely used in clinical settings to image brain tumors, neuroendocrine tumors, prostate cancer, breast cancer, non-small cell lung cancer (NSCLC) and hepatocellular carcinoma. This review focuses on the fundamental concepts and the uptake mechanism of AAs, AA PET tracers and their clinical applications.

Keywords: positron-emitting AAs, carbon-11, fluorine-18, positron emission tomography, imaging, tumors

\section{INTRODUTION}

Positron emission tomography (PET) can provide noninvasive molecular, functional and metabolic information. Thus, it is playing an increasingly important role in the diagnosis and staging of tumors, image-guided therapy planning, and treatment monitoring. $2-{ }^{18} \mathrm{~F}-$ fluoro-2-deoxy-Dglucose $\left({ }^{18} \mathrm{~F}-\mathrm{FDG}\right)$ is a commonly used tracer for PET imaging. Based on the increased rate of glucose transport and glycolysis, the uptake of ${ }^{18} \mathrm{~F}-\mathrm{FDG}$ in tumors cells is greater than that in normal cells. ${ }^{18} \mathrm{~F}-\mathrm{FDG}$ has provided valuable information about tumors diagnosing, staging, and prognosis after surgery and therapy, but it has some limitations. On the one hand, due to the high uptake of ${ }^{18} \mathrm{~F}$-FDG in the normal brain, it is difficult to obtain images with adequate contrast compared to primary or metastatic brain tumors (Zhao et al., 2014). On the other hand, some tumors, such as neuroendocrine tumors, renal cell carcinoma, prostate cancer and hepatocellular carcinoma, show low or nonspecific uptake, which may lead to false negative or positive results (Powles et al., 2007; Rioja et al., 2010; Bouchelouche and Choyke, 2015). Additionally, ${ }^{18}$ F-FDG PET is ambiguous for differentiating tumor from inflammation (Rau et al., 2002; Tang et al., 2003).

Besides glucose, certain AAs also serve as increasing energy sources and anabolic precursors for tumors. Positron nuclide-labeled AA tracers can overcome limitations of ${ }^{18} \mathrm{~F}$-FDG for tumors imaging, and give information about AA metabolism in tumor. The uptake of AA PET tracers in the normal brain is significantly less than that of ${ }^{18} \mathrm{~F}-\mathrm{FDG}$, but the uptake of them in tumor 
is high. Thus, images with adequate contrast can be obtained using AA PET tracers for primary and metastatic brain tumors. Also, some AA PET tracers have an advantage over ${ }^{18}$ F-FDG in the differentiation of tumor from inflammation (Rau et al., 2002; Tang et al., 2003; Stober et al., 2006). It was reported that $\mathrm{O}-\left(2-{ }^{18} \mathrm{~F}\right.$-fluoroethyl)-L-tyrosine $\left({ }^{18} \mathrm{~F}-\mathrm{FET}\right)$ and $\left(\mathrm{S}-{ }^{11} \mathrm{C}\right.$-methyl)L-methionine $\left({ }^{11} \mathrm{C}\right.$-MET) have a significantly higher uptake in tumor cells than that in inflammatory cells. This different appearance can be contributed to major AAs transporter system L (Stober et al., 2006). They can also differentiate recurrent brain tumors from pseudo-progression or radiation necrosis among patients after surgery and radiotherapy (Niyazi et al., 2012; Galldiks et al., 2015a,b). In addition, some AA PET tracers with relatively little renal excretion can accurately detect prostate cancer and show high specificity and sensitivity, superior to ${ }^{18}$ F-FDG (Toth et al., 2005; Jana and Blaufox, 2006). Last, ${ }^{18} \mathrm{~F}-\mathrm{FDG}$ is a nonspecific substrate for neuroendocrine tumors, but a few AA PET tracers are substrates of the enzyme aromatic AA decarboxylase (AADC), which are specific for neuroendocrine tumors imaging, such as 3,4-dihydroxy- $6-{ }^{18} \mathrm{~F}$ fluoro-L-phenylalanine $\left({ }^{18} \mathrm{~F}\right.$-FDOPA $)$ and 5 -hydroxy-L- $\left[\beta-{ }^{11} \mathrm{C}\right]$ tryptophan $\left({ }^{11} \mathrm{C}-\mathrm{HTP}\right)$ (Jager et al., 2008; Oberg and Castellano, 2011). This review focuses on the fundamental concepts of AAs and the uptake mechanism of AAs, AA PET tracers and their clinical applications.

\section{FUNDAMENTAL CONCEPTS AND UPTAKE MECHANISMS OF AAS}

L-AAs, as essential small-molecule nutrient substances, are crucial for maintaining cell growth and nitrogen balance. Their biological functions are involved in metabolism, protein synthesis, cell signaling transduction, regulating gene expression. They are also precursors for the synthesis of hormones, neurotransmitter, and nitrogenous substances. L-AAs are commonly found in proteins and are either obtained from intracellular protein recycling or are transported into the cell from the extracellular surroundings (Stryer, 1995).

The transporters mediate AA transport across plasma membranes in mammals and are divided into several "systems." The systems present various transporting mechanisms, including dependence on sodium and independence on sodium, tissue expression patterns, substrate specificity and sensitivity to $\mathrm{pH}$ or hormones (Utsunomiya-Tate et al., 1996; Castagna et al., 1997). Cells possess different transport systems in their plasma membranes, consisting of generally existed transport systems (such as systems $\mathrm{A}$, ASC, $\mathrm{L}, \mathrm{y}^{+}$and $\mathrm{X}_{\mathrm{AG}^{-}}, \mathrm{X}_{\mathrm{C}^{-}}$), and tissue-specific transport systems (such as systems $\mathrm{B}^{0}$, and $\mathrm{b}^{0,+}$ ) (Palacin et al., 1998). Here, we focus on describing their general features and transport mechanism of AAs, as shown in Table 1 and Figure 1.

System A is $\mathrm{Na}^{+}$-dependent transporter for serving mainly small aliphatic AAs, such as serine, alanine, and glutamine. It is a member of the solute carrier 38 (SLC38) gene family. Three subtypes of system A have been isolated: sodium-coupled neutral AA transporter 1 (SNAT1), 2, and 4. SNAT 3 and 5 belong to the system $\mathrm{N}$ (glutamine preferring) AA transport family, which is also a member of the SLC38 gene family (Broer, 2014). System A and system N are all directly concentrative and function essentially with a monodirectional efflux. System A transports AAs with the $N$-methyl group and $N$-methyl aminoisobutyric acid (MeAIB) is a specific inhibitor that can inhibit system A transport activity due to competitive saturation effects. Meanwhile, the activity of transporters is affected by many factors (Shotwell et al., 1983). The activity of system A is sensitive to $\mathrm{pH}$ alterations, highly down-regulated by acidic extracellular surroundings, and up-regulated by glucagon, insulin, and growth factors (Castagna et al., 1997).

The ASC system is $\mathrm{Na}^{+}$-dependent exchanger capable of mediating net influx or efflux, with substrates (L-alanine, L-serine, L-cysteine, and L-glutamine) and a member of solute the carrier family 1(SLC1) (Castagna et al., 1997). Two subtypes have been isolated: ASC-Type AA transporter 1 (ASCT1) and ASC-Type AA transporter 2 (ASCT2). ASCT2 utilizes an intracellular gradient of AAs, efflux of intracellular AAs in exchange for extracellular AAs. Glutamine is a key substrate of ASCT2 with important roles in tumor metabolism (Fuchs et al., 2007). ASCT2 is over-expressed in many human tumor cell lines including hepatocellular carcinoma, prostate, breast, glioma, and colon tumor cell lines (Li et al., 2003; Fuchs and Bode, 2005). L- $\boldsymbol{\gamma}$-glutamyl-p-nitroanilide (GPNA) is used as a specific inhibitor of ASCT2 transporter activity (Schulte et al., 2015). The activity of system ASC is $\mathrm{pH}$-insensitive within a range of $\mathrm{pH}$ 5.65-8.2 (Fuchs and Bode, 2005; Kanai et al., 2013).

The $\mathrm{Na}^{+}$-independent system $\mathrm{L}$ is the major route that takes up branched and aromatic AAs from the extracellular space, such as phenylalanine, isoleucine, tryptophan, valine, methionine and histidine (Castagna et al., 1997). Four subtypes of system L have been isolated: L-type AA transporters 1 (LAT1), LAT2, LAT3, and LAT4. LAT1 and LAT2 are members of the SLC7 gene family, while LAT3 and LAT4 are members of the SLC43 gene family. LAT1 and LAT2 possess "4F2 light chains" containing 12 putative membrane-spanning domains, which covalently bind a typeII membrane glycoprotein heavy chain (4F2hc) with disulfide bridges to produce a functional heterodimeric transporter. LAT3 and LAT4, without 4F2hc, facilitate the transport of AAs (Fuchs and Bode, 2005; Aiko et al., 2014). System L plays an important role for AAs crossing the placenta barrier and the blood-brain barrier (Christensen, 1990). 2-amino-2-norbornane-carboxylic acid $(\mathrm{BCH})$ is a specific inhibitor for system $\mathrm{L}$ transporter activity (Palacin et al., 1998; Babu et al., 2003).

The cationic AA transporters include systems $\mathrm{B}^{0,+}, \mathrm{y}^{+}$, and $\mathrm{y}^{+} \mathrm{L}$, and the anionic AA transporters contain systems $\mathrm{X}_{\mathrm{AG}^{-}}$and $\mathrm{X}_{\mathrm{C}^{-}}$. Systems $\mathrm{B}, \mathrm{B}^{0}, \mathrm{~B}^{0,+} \mathrm{y}^{+}$, and $\mathrm{y}^{+} \mathrm{L}$ are related $\mathrm{Na}^{+}$-dependent transporter systems. They mediate the absorption of branchedchain, aliphatic and aromatic AAs. Systems B and B ${ }^{0}$ are tissuespecific transport systems and present in renal proximal tubular and intestinal epithelial brush-border membranes. Both systems are more broadly specific for neutral AAs than systems A and ASC. System $\mathrm{y}^{+}$transporters are members of the SLC7 gene family. Four subtypes, CAT-1, CAT-2 (A and B), CAT-3, and 
TABLE 1 | Summary of AA transporters.

\begin{tabular}{|c|c|c|c|c|}
\hline Transporter & Gene name & System and mechanism of transport & Substrate & Inhibitors/blockers \\
\hline SNAT1 & SLC38A1 & $\mathrm{Na}^{+}$-dependent system A, concentrative & Small neutral AAs & MeAIB \\
\hline SNAT2 & SLC38A2 & & & \\
\hline SNAT4 & SLC38A4 & & & \\
\hline ASCT1 & SLC1A4 & $\mathrm{Na}^{+}$-dependent system ASC, exchange & & \\
\hline ASCT2 & ${ }^{*} S L C 1 A 5$ & & $\begin{array}{l}\text { L-Ala, L-Cys, L-Gln, } \\
\text { L-Ser, L-Thr }\end{array}$ & $\begin{array}{l}\text { L- } \gamma \text {-glutamyl-p-nitroanilide } \\
\text { (GPNA) Esslinger et al., 2005; } \\
\text { Schulte et al., } 2015 \\
\text { Benzylserine Jager et al., 2008, } \\
\text { Glupnitroanilide Bhutia et al., } \\
2015\end{array}$ \\
\hline GLYT1, GLYT2 & SLC6 & $\mathrm{Na}^{+}$-dependent system $\mathrm{G}$ & Gly, Sar & \\
\hline SN1, SN2 & SLC38 & $\mathrm{Na}^{+}$-dependent system $\mathrm{N}$, concentrative & Gln, Asn, His & \\
\hline Taut & SLC6 & $\mathrm{Na}^{+}$-dependent $\beta$-system & $\beta$-Ala, Tau & \\
\hline LAT1 & *SLC7A5 & $\begin{array}{l}\mathrm{Na}^{+} \text {-independent system L, Exchange, heterodimer with } \\
4 \mathrm{~F} 2 \mathrm{hc}\end{array}$ & Large neutral L-AAs & $\begin{array}{l}\mathrm{BCH} \\
\text { Rosilio et al., } 2015\end{array}$ \\
\hline LAT2 & SLC7A8 & & & \\
\hline LAT3 & SLC43A1 & $\mathrm{Na}^{+}$-independent system L, Facilitated & & $\begin{array}{l}\mathrm{BCH}, \mathrm{N} \text {-ethylmaleimide } \\
\text { Ogihara et al., } 2015\end{array}$ \\
\hline LAT4 & SLC43A2 & & & \\
\hline Asc-1 Asc-2 & SLC7 & $\mathrm{Na}^{+}$-independent system asc & Ala, Ser, Thr, Cys & \\
\hline TAT1 & SLC16 & $\mathrm{Na}^{+}$-independent system $\mathrm{T}$ & Aromatic AAs & \\
\hline ATB $^{0,+}$ & ${ }^{*} S L C 6 A 14$ & System $\mathrm{B}^{0,+}, \mathrm{Na}^{+}$and $\mathrm{Cl}^{-}$, concentrative & Neutral and basic AAs & $\begin{array}{l}\alpha-\text { Methyl-L-Trp Bhutia et al., } \\
2015\end{array}$ \\
\hline CAT-1 & SLC7A1 & $\mathrm{Na}^{+}$-independent system $\mathrm{y}^{+}$, Facilitated & $\begin{array}{l}\text { Lysine, histidine, } \\
\text { arginine }\end{array}$ & N-ethylmaleimide Nel et al., 2012 \\
\hline CAT-2A/2B & SLC7A2 & & & \\
\hline CAT-3 & SLC7A3 & & & \\
\hline$y^{+}$LAT1 & SLC7A7 & $\begin{array}{l}\mathrm{Na}^{+} \text {-independent system } \mathrm{y}^{+} \mathrm{L} \text {,exchange heterodimer } \\
\text { with } 4 \mathrm{~F} 2 \mathrm{hc}\end{array}$ & $\begin{array}{l}\text { Cationic, large neutral } \\
\text { AAs }\end{array}$ & $\mathrm{BCH}$ selective inhibitor \\
\hline$y^{+}$LAT2 & SLC7A6 & & & \\
\hline BAT1/b0, +AT•rBAT & SLC7 & $\begin{array}{l}\text { System } b^{0,+} \text {, Exchange, heterodimer with } \\
\text { D2/rBAT/NBAT }\end{array}$ & $\begin{array}{l}\text { Cationic, large neutral } \\
\text { AAs }\end{array}$ & $\mathrm{BCH}$ \\
\hline EAAT1 & SLC1A1 & $\begin{array}{l}\text { System } \mathrm{X}_{\mathrm{AG}^{-}}, \mathrm{Na}^{+} \text {cotransport and } \mathrm{K}^{+} \text {counter } \\
\text { transport }\end{array}$ & Glutamate, aspartate & $\begin{array}{l}\text { The phorbol ester 12-myristate } \\
\text { 13-acetate (TPA, 0-1000 nM) } \\
\text { Pan et al., 1995a }\end{array}$ \\
\hline GLT-1(EAAT2) & SLC1A2 & & & \\
\hline GLAST (EAAT3) & SLC1A3 & & & \\
\hline EAAT4 & SLC1A6 & & & \\
\hline EAAT5 & SLC1A7 & & & \\
\hline$x \mathrm{CT}$ & ${ }^{*} S L C 7 A 11$ & $\begin{array}{l}\text { System } \mathrm{X}_{\mathrm{C}^{-}}, \mathrm{Na}^{+} \text {-independent, but } \mathrm{Cl}^{-} \text {dependent } \\
\text { glutamate/cysteine exchange, heterodimer with4F2hc }\end{array}$ & Glutamate/cystine & $\begin{array}{l}\text { Sulfasalazine, Erastin, Sorafenib } \\
\text { (S)-4-Carboxyphenyl glycine } \\
\text { Bhutia et al., } 2015 \\
\text { L-a-aminoadipate } \\
\text { Lewerenz et al., } 2013\end{array}$ \\
\hline
\end{tabular}

*Low-level expression in normal tissues, but up-regulated expression in many human tumors.

AAs, amino acids; MeAIB, N-methyl aminoisobutyric acid; BCH, 2-amino-endo-bicyclo[2,2,1]heptane-2-carboxylic acid. 


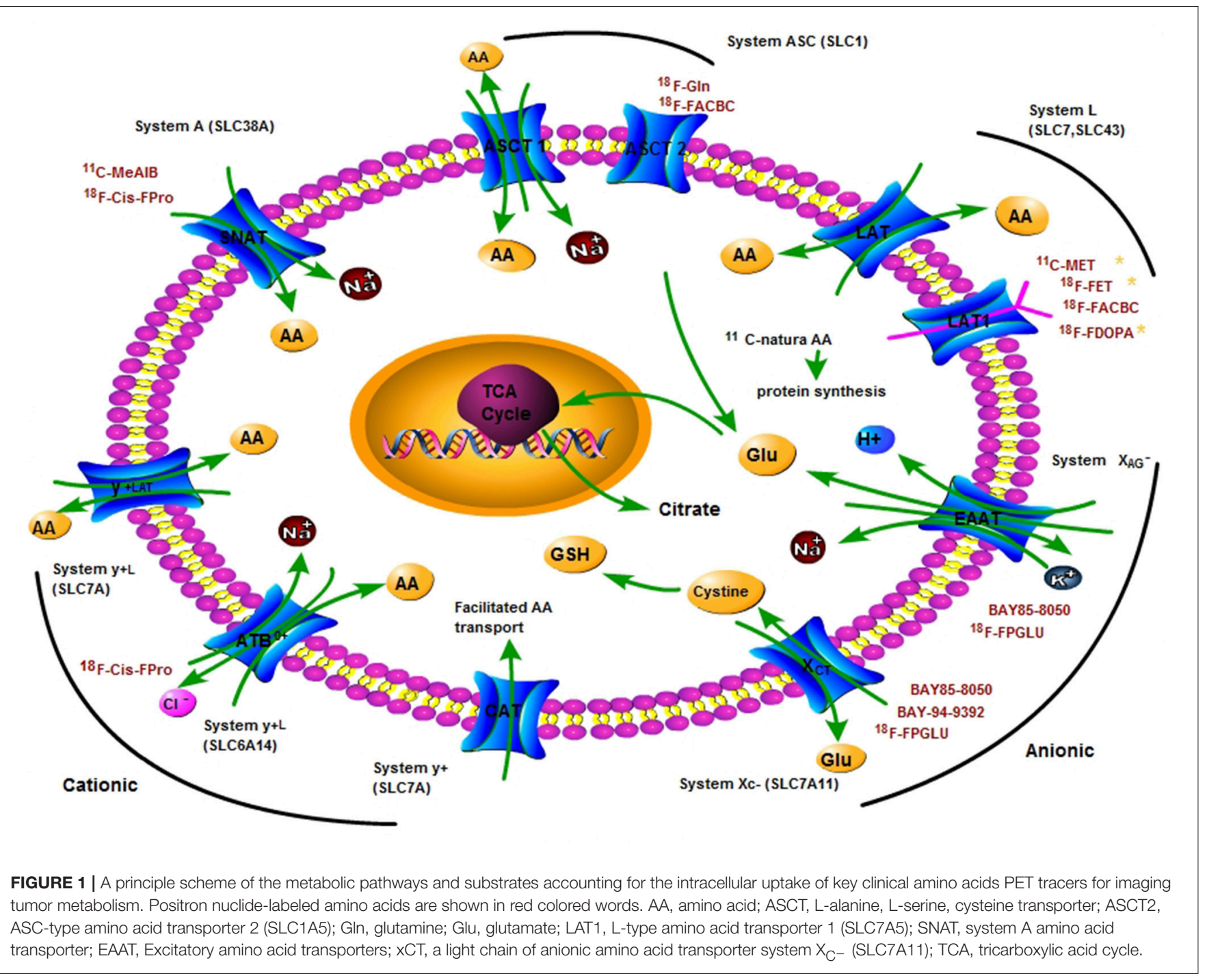

CAT-4, have been recognized from a subfamily of the SLC7 gene family. CAT-1 is a exchanger targeting unessential AAs, and the action of CAT-4 remains unknown (Hammermann et al., 2001). System $\mathrm{y}^{+}$transports cationic AAs and some neutral AAs, such as lysine and arginine, resulting in electrogenic transport (Castagna et al., 1997; Palacin et al., 1998). System $\mathrm{y}^{+} \mathrm{L}$ transporters are members of the SLC7 gene family as well. Two subtypes $\left(y^{+}\right.$LAT1 and $\mathrm{y}^{+}$LAT2) have been identified, and they create heterodimers with the $4 \mathrm{~F} 2 \mathrm{hc}$ glycoprotein to be functional AA transporters, such as the LAT1 and LAT2 transporters from system L. System $\mathrm{y}^{+} \mathrm{L}$ serves large neutral and cationic AAs with an exchange mechanism. $\mathrm{ATB}^{0,+}$ belongs to the SLC6 gene family and serves cationic and neutral AAs in the presence of sodium and chloride. $\mathrm{b}^{0,+}$ AT belongs to the SLC7 gene family, which constitutes a functional heterodimer with the glycoprotein D2/rBAT/NBAT and serves cationic and neutral AAs via an exchange mechanism in the absence of sodium (Torrents et al., 1998; Hammermann et al., 2001).

System $\mathrm{X}_{\mathrm{C}^{-}}$is $\mathrm{Na}^{+}$-independent and $\mathrm{Cl}^{-}$-dependent heterodimeric AA transporter (Baker et al., 2002; Lewerenz et al., 2012, 2013), an obligate, electroneutral, cysteine/glutamate antiporter, exchanges extracellular cystine for intracellular glutamate (Lo et al., 2008; Lewerenz et al., 2012). It is composed of a subunit $\mathrm{xCT}$ light chain and a subunit 4F2 heavy chain (4F2hc). $\mathrm{xCT}$ is a member of SLC7, member 11 (SLC7A11), and phosphorylation of $\mathrm{xCT}$ can modulate the activity of system $\mathrm{X}_{\mathrm{C}^{-}}$ (Baker et al., 2002; Lo et al., 2008; Lewerenz et al., 2012). It is not only a potential target for therapy but also a potential PET biomarker for imaging the system $\mathrm{X}_{\mathrm{C}^{-}}$activity of cancer and other diseases (Lo et al., 2008; Reissner and Kalivas, 2010; Koglin et al., 2011).

System $\mathrm{X}_{\mathrm{AG}^{-}}$is $\mathrm{Na}^{+}$-dependent and $\mathrm{K}^{+}$-dependent and transports acidic AAs, such as glutamate and aspartate (Dall'Asta et al., 1983; Pan et al., 1995b). Excitatory AA transporters EAAT1 (GLAST), EAAT2 (GLT-1), EAAT3 (EAAC1), and EAAT4 are members of the system $\mathrm{X}_{\mathrm{AG}^{-}} \mathrm{AA}$ transport family (Howell et al., 2001) and are neuronal/epithelial high affinity glutamate transporters (Yin et al., 2014). They are encoded by the SLC1A1, SLC1A2, SLC1A3, SLC1A6, SLC1A7, respectively (Kanai et al., 2013; Bianchi et al., 2014). 
The transporter systems mentioned above are the main targets for AA metabolism PET imaging of tumors (Jager et al., 2001). Tumor cells utilize more AAs compared with normal cells to satisfy their rapid proliferation and invasion demands. And studies indicated that the expression of AA transporters is higher in tumor cells than that in normal tissue, especially LAT1, ASCT2, xCT, and $\mathrm{ATB}^{0,+}$ and so on (Karunakaran et al., 2011; Toyoda et al., 2014; Schulte et al., 2015). Both ASCT2 and LAT1 are upregulated three-fold in the most of cancerous tissues. LAT1 has been proven to be associated with tumor growth (Kaira et al., 2013), for example ${ }^{11} \mathrm{C}$-MET, ${ }^{18} \mathrm{~F}$-FET, and ${ }^{18} \mathrm{~F}$-FDOPA are the most widely used AA PET tracers for imaging brain tumors. System A and cationic or anionic AA transporters are overexpressed in dividing cells in certain human cancers (Bussolati et al., 1996). Many examples are showed in Table 2 . Tumor cell accumulation of AA PET tracers mainly depends on the rate and mechanism of AAs transport. Based on the over-expression of AA transporters, the uptake of AA PET tracers in tumor cells is greater than that in normal cells (Mossine et al., 2016).

\section{AA PET TRACERS}

Most AA PET tracers are labeled with positron radionuclides ${ }^{11} \mathrm{C}$ and ${ }^{18} \mathrm{~F}$. Theoretically, almost all AAs be labeled with ${ }^{11} \mathrm{C}$, however, their short half-life $(20 \mathrm{~min}, 100 \%$ of beta positron decay) is not suitable for delayed PET imaging. To overcome this shortcoming of ${ }^{11} \mathrm{C}$ and to facilitate the utility of AA PET tracers in hospitals without on-site cyclotron and labeling equipment, a series of ${ }^{18} \mathrm{~F}$ labeled AAs (half-life of $110 \mathrm{~min}$, 97\% of beta positron decay) were developed (Mossine et al., 2016). Based on that AAs have a common molecular formula [R-CH- $\left(\mathrm{NH}_{2}\right)-\mathrm{COOH}$, with a carboxylic acid group $(-\mathrm{COOH})$, an amino group $\left(-\mathrm{NH}_{2}\right)$ linking to the alpha-carbon atom $(-\mathrm{CH}-)$, and branched-chain group $(-\mathrm{R})$. Thus, ${ }^{11} \mathrm{C}$ and ${ }^{18} \mathrm{~F}$ labeled AAs are divided into $\left[1-{ }^{11} \mathrm{C}\right]$ AAs $\left(\left[1-{ }^{11} \mathrm{C}\right] \mathrm{AAs}\right)$, alphaC labeled AAs (alpha-C labeled AAs), labeled branched-chain AAs (branched-chain AAs), and $N$-substituted labeled AAs ( $N$-substituted labeled AAs), which include natural and nonnatural AAs.

Labeled natural AAs associated with structure-changed and structure-unchanged labeled AAs. Structure-unchanged labeled natural AAs, such as $\left[1-{ }^{11} \mathrm{C}\right]$ AAs and ${ }^{11} \mathrm{C}-$ Met, do not chemically change the structure of AAs and can maintain the prototype structure and the fundamental pharmacodynamics and pharmacokinetics characteristics of AAs. So, they are mainly incorporated into protein synthesis, with minor AA transport. On the contrary, structure-changed labeled AAs (such as ${ }^{18} \mathrm{~F}$-FET, (S- ${ }^{11} \mathrm{C}$-methyl)-L-cysteine) do chemically change the structure of AAs, which are slightly incorporated into protein synthesis. Like structure-changed labeled AAs, labeled non-natural AAs (such as ${ }^{18}$ F-FDOPA, ${ }^{11} \mathrm{C}-\mathrm{HTP}$ ) are mainly involved into AA transport. Most important ${ }^{11} \mathrm{C}$ - and ${ }^{18} \mathrm{~F}$-labeled $\mathrm{AA}$ tracers are shown in Table 2.

$\left[1-{ }^{11} \mathrm{C}\right] \mathrm{AAs}$ have ${ }^{11} \mathrm{C}$-labeled at the alpha-carboxylate $(-\mathrm{COOH})$ position, $\left[1{ }^{11} \mathrm{C}\right]$-labeled natural AAs such as L-[1$\left.{ }^{11} \mathrm{C}\right]$-leucine $\left({ }^{11} \mathrm{C}-\mathrm{Leu}\right)$ (Veronese et al., 2012), L- $\left[1-{ }^{11} \mathrm{C}\right]$ tyrosine $\left({ }^{11} \mathrm{C}-\mathrm{Tyr}\right)$ (de Boer et al., 2003), L- $\left[1-{ }^{11} \mathrm{C}\right]$ phenylalanine $\left({ }^{11} \mathrm{C}\right.$ Phe) (Lebarre et al., 1991) and L- $\left[1-{ }^{11} \mathrm{C}\right]$ methionine $\left({ }^{11} \mathrm{C}-\mathrm{Met}\right)$ (Ishiwata et al., 1988) are mainly incorporated into protein synthesis, and can be used to measure the rates of the protein synthesis. $\left[1-{ }^{11} \mathrm{C}\right]$-labeled non-natural AAs, such as carboxyl- ${ }^{11} \mathrm{C}-1-\alpha$-aminoisobutyric acid $\left({ }^{11} \mathrm{C}-\mathrm{AIB}\right)$, carboxyl${ }^{11} \mathrm{C}$-1-aminocyclopentanecarboxylic acid $\left({ }^{11} \mathrm{C}-\mathrm{ACPC}\right)$, and carboxyl- ${ }^{11} \mathrm{C}$-1-aminocyclopentane carboxylic acid $\left({ }^{11} \mathrm{C}\right.$ $\mathrm{ACBC}$ ), etc., are not incorporated into protein synthesis and have been used for imaging of tumor AA transport in several studies (Washburn et al., 1978; De Vis et al., 1987).

Labeled alpha-carbon AAs have radiolabeled at alphacarbon (-CH-) position of AAs, which are rarely reported. $\alpha-\left[{ }^{11} \mathrm{C}\right.$-methyl $]-\mathrm{L}$-tryptophan $\left({ }^{11} \mathrm{C}-\mathrm{AMT}\right)$ and $\alpha-\left[{ }^{11} \mathrm{C}\right.$-methyl $]-$ aminoisobutyric acid $\left({ }^{11} \mathrm{CH}_{3}\right.$-AIB) are typical examples that have been used for tumors imaging by measuring the rate of $\mathrm{AA}$ transport (Juhasz et al., 2011).

Labeled branched-chain AAs have radiolabeled at branchedchain group (-R) of AAs. Labeled branched-chain natural AAs with unchanged structure are rare, for example (S-[ $\left.{ }^{11} \mathrm{C}\right]$ methyl)L-methionine $\left({ }^{11} \mathrm{C}-\mathrm{MET}\right)$. Most labeled branched-chain natural AAs are changed into different structure labeled AAs from natural AAs, such as ${ }^{18}$ F-FET, $2-{ }^{18}$ F-fluoro-L-tyrosine (2-FTYR), $6-{ }^{18} \mathrm{~F}-\mathrm{L}-\mathrm{m}$-tyrosine $\quad\left({ }^{18} \mathrm{~F}-\mathrm{FMT}\right), \quad \mathrm{O}-\left(3-{ }^{18} \mathrm{~F}\right.$-fluoropropyl $)-\mathrm{L}$ tyrosine $\left({ }^{18} \mathrm{~F}-\mathrm{FPT}\right), 2-{ }^{18} \mathrm{~F}-\mathrm{L}$-phenylalanine, cis- ${ }^{18} \mathrm{~F}$-fluoroproline (cis-Fpro), (4S)-4-(3-18 F-fluoropropyl)-L-glutamate (BAY 94-9392, ${ }^{18}$ F-FSPG), (2S,4R)-4- ${ }^{18}$ F-L-glutamate (BAY85-8050, 4F-GLU), L-(5- $\left.{ }^{11} \mathrm{C}\right)$-glutamine, $\quad(2 \mathrm{~S}, 4 \mathrm{R})-4-{ }^{18} \mathrm{~F}-\mathrm{L}$-glutamine $\left({ }^{18} \mathrm{~F}-(2 S, 4 R) 4 \mathrm{~F}-\mathrm{GLN}\right),(2 \mathrm{~S}, 4 \mathrm{~S})-4-\left(3-{ }^{18} \mathrm{~F}-\right.$ fluoropropyl) glutamine $\left({ }^{18} \mathrm{~F}-\mathrm{FPGln}\right)$, and $\left(\mathrm{S}-{ }^{11} \mathrm{C}\right.$-methyl)-L-cysteine $\quad\left({ }^{11} \mathrm{C}-\mathrm{MCYS}\right)$ (Deng et al., 2011; Huang et al., 2015). Labeled branched-chain non-natural AAs include labeled branched-chain D-AAs and labeled branched-chain L-non-natural AAs. The former includes D- ${ }^{11} \mathrm{C}$-fluoromethyltyrosine, D- ${ }^{18} \mathrm{~F}$-fluoromethyltyrosine $\left({ }^{18} \mathrm{~F}\right.$ D-FMT) (Burger et al., 2014) and (S- ${ }^{11} \mathrm{C}$-methyl)-D-cysteine $\left({ }^{11} \mathrm{C}\right.$-DMCYS) (Huang et al., 2015). The latter includes $3-{ }^{18} \mathrm{~F}-\alpha-$ methyltyrosine ( ${ }^{18} \mathrm{~F}$-FAMT), 1-amino-3- ${ }^{18} \mathrm{~F}$-fluorocyclobutane1-carboxylic acid ( $\left.{ }^{18} \mathrm{~F}-\mathrm{FACBC}\right), \quad 3-\mathrm{O}$-methyl-6- ${ }^{18} \mathrm{~F}-\mathrm{L}-3$, 4-dihydroxyphenylalanine ( ${ }^{18} \mathrm{~F}$-OMFD), (S)-2-amino-3-[1$\left(2-{ }^{18} \mathrm{~F}\right.$-fluoroethyl)-1H-[1,2,3]triazol-4-yl]propanoic acid $\left({ }^{18} \mathrm{~F}\right.$-AFETP), $3{ }^{-18} \mathrm{~F}$-2-methyl-2-(methylamino)propanoic acid $\left({ }^{18} \mathrm{~F}-\mathrm{MeFAMP}\right), \quad 3,4$-dihydroxy-6- ${ }^{18} \mathrm{~F}$-L-phenylalanine $\quad\left({ }^{18} \mathrm{~F}\right.$ FDOPA), anti-1-amino-2- ${ }^{18} \mathrm{~F}$-fluorocyclopentane-1-carboxylic acid (anti-2- $\left.{ }^{18} \mathrm{~F}-\mathrm{FACPC}\right), 5-{ }^{18} \mathrm{~F}-\mathrm{L}$-aminosuberic acid $\left({ }^{18} \mathrm{~F}-\mathrm{FASu}\right)$, ${ }^{11} \mathrm{C}-\mathrm{HTP}, \mathrm{L}-\left[\beta-{ }^{11} \mathrm{C}\right] \mathrm{DOPA}\left({ }^{11} \mathrm{C}-\mathrm{DOPA}\right), \mathrm{L}-\left[\beta-{ }^{11} \mathrm{C}\right]$ dopamine, and ${ }^{18} \mathrm{~F}$-fluoropropyl-L-tryptophan $\left({ }^{18} \mathrm{~F}\right.$-FPTP) (Jager et al., 2001; McConathy and Goodman, 2008; McConathy et al., 2012; He et al., 2013; Huang and McConathy, 2013b; Webster et al., 2014). Among these, ${ }^{18}$ F-FAMT, ${ }^{18}$ F-FET, ${ }^{18}$ F-D-FMT, 2-FTYR, ${ }^{18}$ F-FDOPA, ${ }^{18}$ F-FMT, ${ }^{18}$ F-Cis-FPro, ${ }^{18}$ F-OMFD, ${ }^{18}$ F-FACBC, ${ }^{18}$ F-FACPC, ${ }^{11} \mathrm{C}-\mathrm{HTP},{ }^{11} \mathrm{C}-\mathrm{DOPA}$, BAY 94-9392, BAY85-8050 and ${ }^{18} \mathrm{~F}-(2 S, 4 R) 4 \mathrm{~F}-\mathrm{GLN}$ have been used in clinical PET imaging of tumors. Most of labeled branched-chain non-natural AAs are involved in AA transport and a few are incorporated into protein synthesis. However, 2-FTYR and ${ }^{18} \mathrm{~F}$-Cis-Fpro are involved in AA transport and protein synthesis (Jager et al., 2001; Laverman et al., 2002). 
TABLE 2 | Uptake mechanism and clinical application of important AA PET tracers for tumors imaging.

\begin{tabular}{|c|c|c|c|}
\hline Tracer & Labeling position & Mechanism and transporter & Application \\
\hline${ }^{11} \mathrm{C}-$ Leu, ${ }^{11} \mathrm{C}-\mathrm{Tyr},{ }^{11} \mathrm{C}-\mathrm{Phe}$ & {$\left[1-{ }^{11} \mathrm{C}\right] \mathrm{COOH}$} & Protein synthesis & Brain tumors, in vivo protein synthesis rate \\
\hline${ }^{11} \mathrm{C}-\mathrm{AlB},{ }^{11} \mathrm{C}-\mathrm{Met}$ & & System A transport & $\begin{array}{l}\text { Sarcoma, melanoma Lebarre et al., 1991; } \\
\text { de Boer et al., 2003; Veronese et al., } \\
\text { 2012; Nishii et al., } 2013\end{array}$ \\
\hline${ }^{11} \mathrm{CH} 3-\mathrm{AlB}$ & Labeled $\alpha$-carbon & System A transport & Head and neck cancer \\
\hline${ }^{11} \mathrm{CH} 3-\mathrm{AMT}$ & & & Glioma Juhasz et al., 2011 \\
\hline${ }^{11} \mathrm{C}-\mathrm{HTP},{ }^{11} \mathrm{C}-\mathrm{DOPA}$ & Labeled branched-chain & System L transport & $\begin{array}{l}\text { Neuroendocrine tumors Toumpanakis } \\
\text { et al., } 2014\end{array}$ \\
\hline${ }^{11} \mathrm{C}-\mathrm{MET}^{*}$ & & $\begin{array}{l}\text { System L (LAT1) transport/protein } \\
\text { synthesis }\end{array}$ & $\begin{array}{l}\text { Brain tumors and prostate cancer } \\
\text { Ceyssens et al., 2006; Jana and Blaufox, } \\
2006\end{array}$ \\
\hline${ }^{11} \mathrm{C}-\mathrm{MCYS}$ & & $\begin{array}{l}\text { System L, ASC and } \mathrm{B}^{0,+} \\
\text { transport }\end{array}$ & $\begin{array}{l}\text { Brain tumors Deng et al., 2011; Huang } \\
\text { et al., } 2015\end{array}$ \\
\hline${ }^{18} \mathrm{~F}_{-F D O P A}{ }^{*}$ & & System L (LAT1) transport & Brain tumors, neuroendocrine tumors \\
\hline${ }^{18} \mathrm{~F}-\mathrm{OMFD}$ & & System L (LAT1) transport & Brain tumors Gulyas and Halldin, 2012 \\
\hline${ }^{18} \mathrm{~F}_{-} \mathrm{FET}^{\star}$ & & System L transport & Brain tumors Mossine et al., 2016 \\
\hline${ }^{18} \mathrm{~F}-\mathrm{FMT}$ & & System L (LAT1) transport & Brain tumors \\
\hline${ }^{18} \mathrm{~F}-\mathrm{FG}$ In & & System L transport & Brain tumors Gulyas and Halldin, 2012 \\
\hline 8F-2S,4S-FSPG (BAY 94-9392) & & System L and ASC transport & $\begin{array}{l}\text { Hepatocellular carcinoma, in non-small cell } \\
\text { lung cancer Chopra, } 2004\end{array}$ \\
\hline BAY 85-8050 & & System $\mathrm{X}_{\mathrm{C}^{-}}$transport & Healthy volunteers Smolarz et al., 2013b \\
\hline${ }^{18}$ F-FAMT & & System $\mathrm{X}_{\mathrm{C}^{-}}$and $\mathrm{X}_{\mathrm{AG}^{-}}$transport & $\begin{array}{l}\text { Head and neck cancer, lung cancer } \\
\text { Miyakubo et al., } 2007\end{array}$ \\
\hline${ }^{18}$ F-FACBC, ${ }^{18}$ F-FACPC & & System L transport & Prostate cancer Schuster et al., 2011 \\
\hline${ }^{11} \mathrm{C}-\mathrm{MeAIB}$ & $N$-substituted labeled & System A transport & Head and neck cancer Sutinen et al., 2003 \\
\hline${ }^{18}$ F-Cis-FPro & $\begin{array}{l}\text { Labeled branched-chain/ } \\
N \text {-substituted labeled }\end{array}$ & $\begin{array}{l}\text { System } \mathrm{A} \text { and system } \mathrm{B}^{0+} \\
\text { transport/protein synthesis }\end{array}$ & $\begin{array}{l}\text { Head and neck cancer, pulmonary, and } \\
\text { mediastinal mass Stoffels et al., } 2008\end{array}$ \\
\hline
\end{tabular}

*The most widely used AAs PET tracers in clinical settings.

$N$-substituted labeled AAs have radiolabeled at $-\mathrm{NH}_{2}$ group of AAs. $\alpha$-[N-methyl- $\left.{ }^{11} \mathrm{C}\right]$-methylaminoisobutyric acid $\left({ }^{11} \mathrm{C}-\mathrm{MeAIB}\right)$ and $\alpha-\left(N-\left[1-{ }^{11} \mathrm{C}\right]\right.$ acetyl $)$-aminoisobutyric acid (Prenant et al., 1996) are $N$-substituted labeled nonnatural AAs targeting transport system A. ${ }^{11} \mathrm{C}-\mathrm{MeAIB}$ has been used for clinical PET imaging of tumor (Sutinen et al., 2003). Although several $N$-substituted labeled natural AAs, such as $\mathrm{p}^{-18} \mathrm{~F}$-fluorohippurate $\left({ }^{18} \mathrm{~F}-\mathrm{PFH}\right)$ as a glycine analog, have been reported, their transport mechanisms remain unknown (Awasthi et al., 2011). N-substituted labeled natural AAs targeting different AA transport systems, such as $\quad N-\left(2-{ }^{18}\right.$ F-fluoropropionyl $)-\mathrm{L}-m e t h i o n i n e \quad\left({ }^{18} \mathrm{~F}-\mathrm{FPMET}\right)$, $\mathrm{N}$-(2- ${ }^{18} \mathrm{~F}$-fluoropropionyl)-L-glutamic acid $\left({ }^{18} \mathrm{~F}-\mathrm{FPGLU}\right), \mathrm{N}-(2-$ ${ }^{11} \mathrm{C}$-methyl)-L-glutamic acid $\left({ }^{11} \mathrm{C}\right.$-MGLU), were first reported by our research group (Hu et al., 2013, 2014). ${ }^{18} \mathrm{~F}-\mathrm{FPGLU}$ is a potential AA PET tracer for tumor imaging and can be used for clinical tumor imaging in the near future. Our studies showed that ${ }^{18} \mathrm{~F}-\mathrm{FPGLU}$ is mainly transported via $\mathrm{X}_{\mathrm{AG}^{-}}$and $\mathrm{X}_{\mathrm{C}^{-}}$( shown in Figure 1) (Hu et al., 2014; Tang et al., 2015).

\section{CLINICAL APPLICATIONS}

AA PET tracers were first used to measure the rate of protein synthesis in vivo (Vaalburg et al., 1992; Ishiwata et al., 1993;
Paans et al., 1996). For example, ${ }^{11} \mathrm{C}$-labeled natural AAs, such as L-leucine, L-methionine, L-phenylalanine and L-tyrosine, are used to measure the protein synthesis rate since they incorporate into proteins or wash out with decarboxylation and oxidation (Ishiwata et al., 1996; Langen et al., 2006). Nowadays, AA transports seem to be more important than protein synthesis for the imaging of tumor metabolism in vivo (Ploessl et al., 2012; Lewis et al., 2015). A wide range of ${ }^{11} \mathrm{C}$ and ${ }^{18} \mathrm{~F}$ AAs have been developed as PET tracers for clinical tumor imaging, as shown in Table 2 and Figure 2. The established AA tracers are used for imaging of brain tumors, neuroendocrine tumors, and prostate cancer, and other tumors.

\section{Brain Tumor}

Though ${ }^{18}$ F-FDG has been used in PET imaging of brain tumors, there exists weaknesses as mentioned (Olivero et al., 1995; Suchorska et al., 2014; Zhao et al., 2014; Tomura et al., 2015). AA PET tracers can overcome its limitations and provide a better description of tumor boundaries, which is important for surgical interventions, targeting biopsies, and radiation therapy (Suchorska et al., 2014). And ${ }^{18}$ F-FDG has been replaced by AA PET tracers or its analogs in clinical settings. The most widely used AA PET tracers are ${ }^{11} \mathrm{C}$-MET, ${ }^{18} \mathrm{~F}$-FET, and ${ }^{18} \mathrm{~F}$-FDOPA (Gulyas and Halldin, 2012; Wang et al., 2014). 


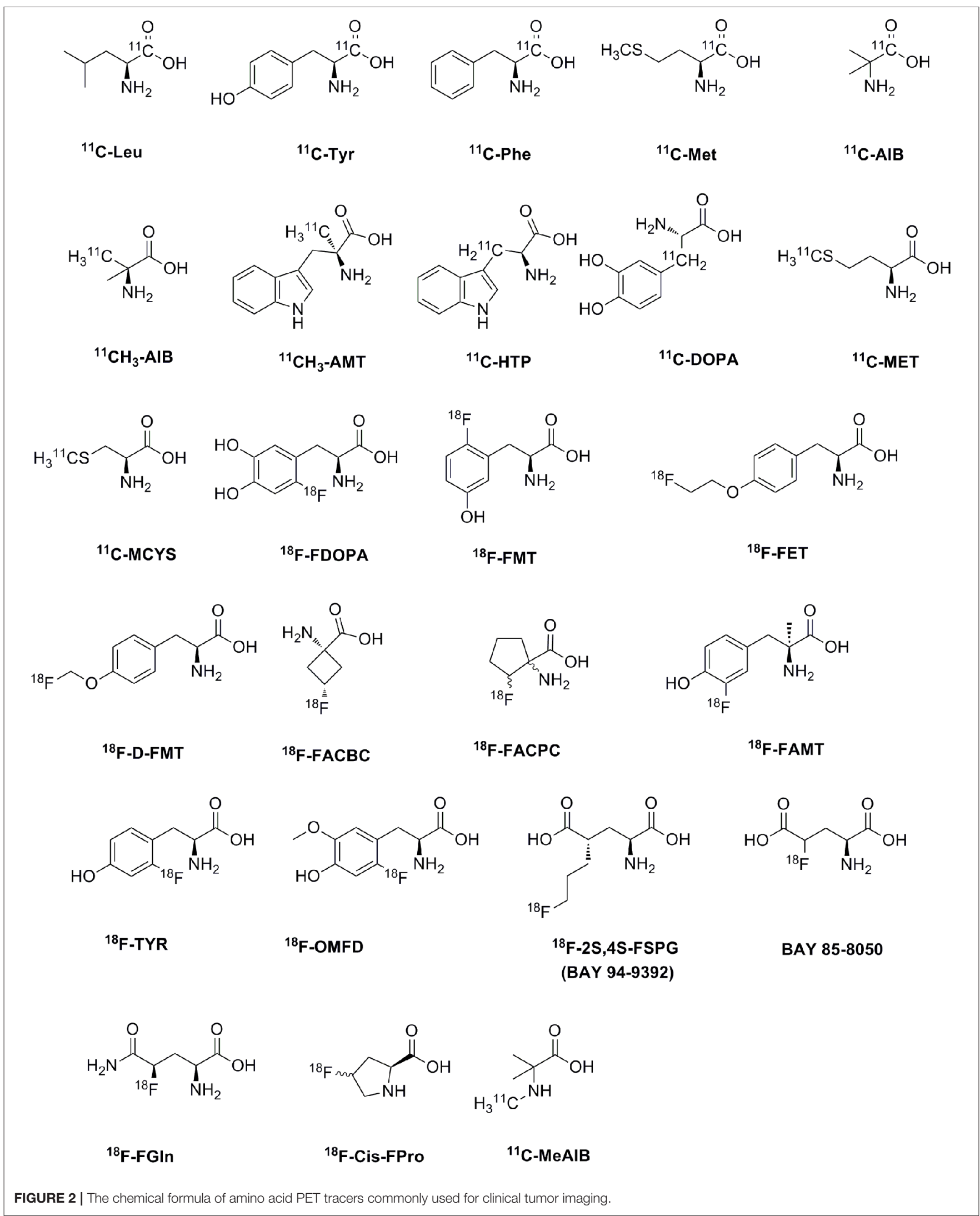



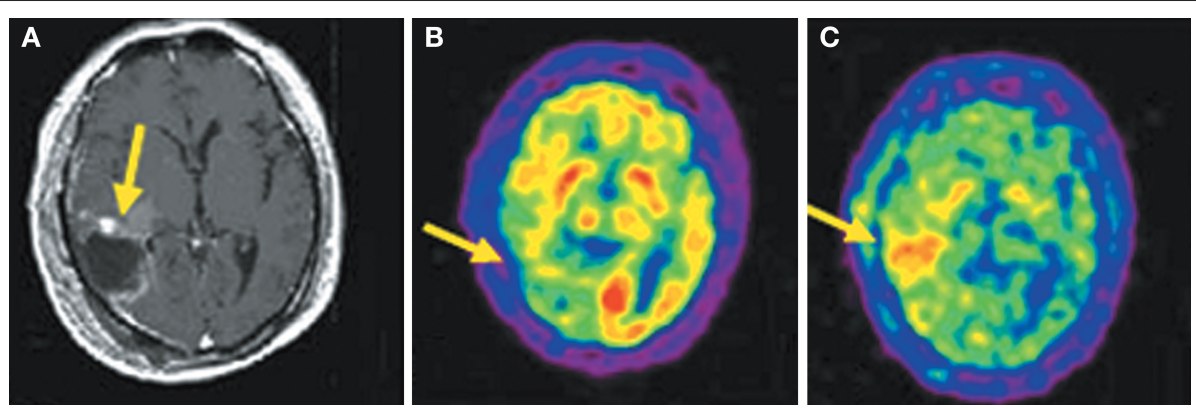

FIGURE 3 | Images (Axial) of a 45-year-old man with a history of attempted resection of World Health Organization (WHO) grade glioma. (A) Subsequent new abnormal enhancing lesion (arrow) on Magnetic resonance (MRI). (B) ${ }^{18}$ F-FDG PET imaging illustrated patching-shaped hypormetabolism in the right temporal lobe (arrow). (C) ${ }^{11} \mathrm{C}-\mathrm{MCYS}$ PET imaging showed a patching-shaped hyperrmetabolism lesion (arrow), which was predominant high-grade tumor recurrence confirmed on histopathology. This figure is reproduced with permission from Deng et al. (2011), Figure 5 @ by the Society of Journal of Nuclear Medicine Imaging, Inc.

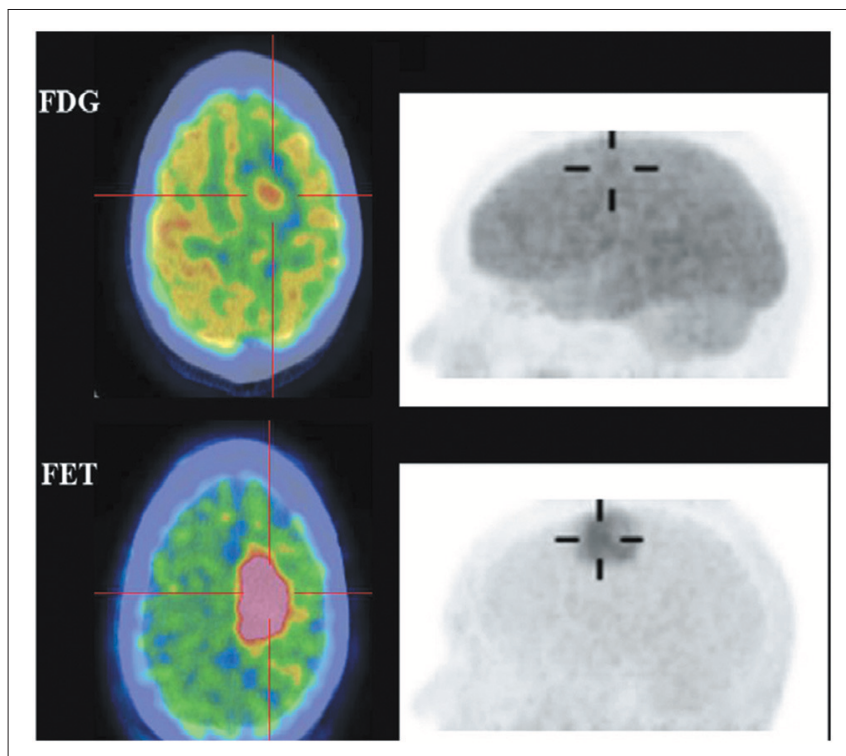

FIGURE 4 | Images of a patient with recurrent glioma of World Health Organization (WHO) grade II oligodendrocytoma histologyon the background of $\mathrm{WHO}$ grade III anaplastic astrocytoma on initial diagnosis. Axial ${ }^{18}$ F-FDG (top), ${ }^{18}$ F-FET (bottom) fused PET/CT (left) and lateral maximum intensity projection images (right). ${ }^{18} \mathrm{~F}$-FET imaging illustrated that the recurrent tumor in the right frontal lobe (cross-hairs) was better visualized and defined, and had a much lower brain uptake background to allow a good tumor-background contrast. This figure is reproduced with permission from Lau et al. (2010), Figure 4 ( ) by the Society of Journal of Clinical Neuroscience, Inc.

Compared to ${ }^{18} \mathrm{~F}-\mathrm{FDG}$, the superior diagnostic accuracy of ${ }^{11} \mathrm{C}$-MET has been demonstrated in detecting, grading, delineating and searching recurrences, prediction of prognosis and evaluation of response to treatment (Nariai et al., 2005; Van Laere et al., 2005; Ceyssens et al., 2006; Galldiks et al., 2006). However, the sensitivity of ${ }^{11} \mathrm{C}-\mathrm{MET}$ was lower in the studies with high proportions of low-grade glioma (Hatakeyama et al., 2008; Glaudemans et al., 2013), which is the most universal type of primary brain tumor. Moreover, there is not yet enough evidence about grading glioma, and its use in differentiating tumor recurrences from radiation necrosis is controversial (Ishii et al., 1993; Sonoda et al., 1998; Nakagawa et al., 2002; Tsuyuguchi et al., 2004; Minamimoto et al., 2015). ${ }^{11}$ C-MCYS, a new AA PET tracer for tumor imaging, is reported that it, as analog of ${ }^{11} \mathrm{C}-\mathrm{MET}$, appeared to have potential value as a tumor PETimaging tracer (Figure 3) (Deng et al., 2011; Huang et al., 2015).

${ }^{18}$ F-FET and ${ }^{18}$ F-FDOPA are derivatives of ${ }^{18} \mathrm{~F}$-labeled Lphenylalanine and L-tyrosine, which target system $\mathrm{L}$ transporters to detect brain tumors. ${ }^{18} \mathrm{~F}$-FET provides both good-contrast PET images of brain tumors (Figure 4) (Langen et al., 2006; Lau et al., 2010; Dunet et al., 2012) and valuable information about differentiating low-grade from high-grade tumor (Popperl et al., 2007; Dunet et al., 2012; Jansen et al., 2015). Dynamic ${ }^{18} \mathrm{~F}$-FET examinations show high diagnostic accuracy in patients with suspected tumor progression or recurrence in clinical settings (Lau et al., 2010; Dunet et al., 2012). ${ }^{18}$ F-FET also can differentiate recurrent brain tumor from pseudoprogression and radiation necrosis (Niyazi et al., 2012; Galldiks et al., 2015a,b). Additionally, ${ }^{18}$ F-FET has a lower uptake by inflammatory cells than ${ }^{11} \mathrm{C}$-MET or ${ }^{18} \mathrm{~F}$-FDG and it clearly delineates tumors from inflammation (Gulyas and Halldin, 2012; Nedergaard et al., 2014).

${ }^{18} \mathrm{~F}$-FDOPA is an analog of L-dopa, and ${ }^{18} \mathrm{~F}-\mathrm{OMFD}$ is a major metabolite of ${ }^{18}$ F-FDOPA (Beuthien-Baumann et al., 2003; Gulyas and Halldin, 2012). ${ }^{18}$ F-FDOPA has been used to investigate the activity of aromatic L-AA decarboxylase and to evaluate the dopaminergic system functioning in brain tumors and neuroendocrine tumors. ${ }^{18}$ F-FDOPA has been used for detecting primary, metastatic and recurrent brain tumors, and provides valuable information on the delineation of tumor volume, the determination of proliferative activities and grading (Figure 5) (Chen et al., 2006; Fueger et al., 2010; Pafundi et al., 2013; Juhász et al., 2014). The uptake of ${ }^{18}$ F-FDOPA correlates with the glioma grade, thus it plays an important role for managing patients in clinical settings (Fueger et al., 2010; Walter et al., 2012; Pafundi et al., 2013).

There are several AA PET tracers of imaging glutaminolysis, such as $\mathrm{L}-\left[5-{ }^{11} \mathrm{C}\right]$-glutamine $(\mathrm{Qu}$ et al., 2012) $4-{ }^{18} \mathrm{~F}-(2 \mathrm{~S}, 4 \mathrm{R})$-fluoroglutamine $\left({ }^{18} \mathrm{~F}-\mathrm{FGln}\right)$ (Lieberman et al., 2011), and (2S,4S)-4-(3- ${ }^{18}$ F-fluoro-propyl)glutamine 

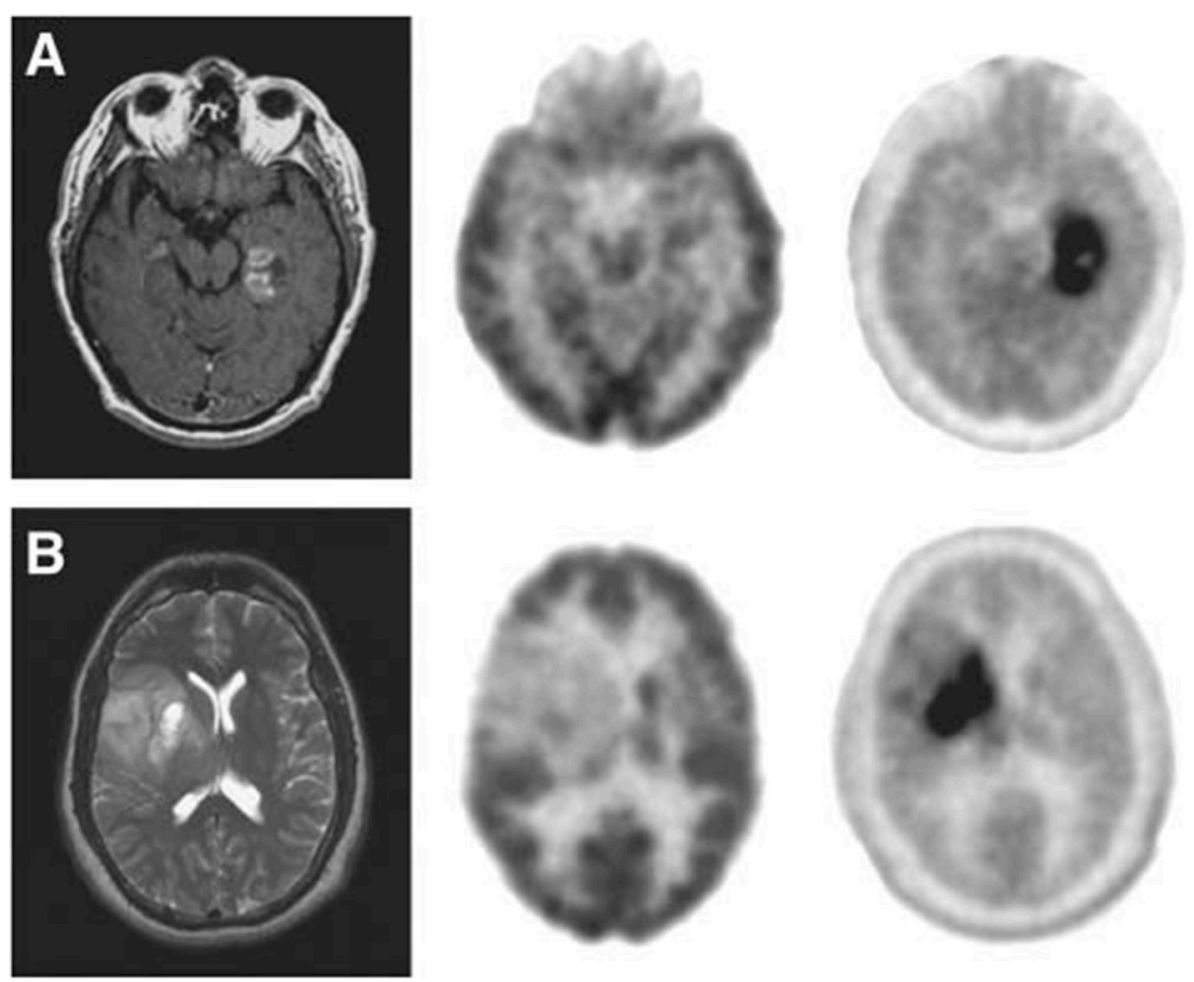

FIGURE 5 | (A) Images of a newly diagnosed glioblastoma. (B) Images of a newly diagnosed World Health Organization grade II oligodendroglioma. Magnetic resonance (left), ${ }^{18}$ F-FDG PET (middle), and ${ }^{18}$ F-FDOPA PET (right). ${ }^{18} \mathrm{~F}$-FDOPA PET imaging illustrated significantly better visualized and defined tumor with adequate contrast. This figure is reproduced with permission from Chen et al. (2006), Figure $2 \odot$ by the Society of Journal of Nuclear Medicine Imaging, Inc.

$\left({ }^{18}\right.$ F-FPGln) (Lewis et al., 2015). Study showed that high uptake of ${ }^{18} \mathrm{~F}$-FGln in glioma, and ${ }^{18} \mathrm{~F}$-FGln may be a helpful tracer for glioma imaging (Venneti et al., 2015).

\section{Neuroendocrine Tumors}

Neuroendocrine tumors (NETs) are a heterogeneous group of neoplasms from cells of the endocrine and nervous systems. Identifying the accurate location of primary tumors and metastases are essential for the treatment of NETs. ${ }^{18} \mathrm{~F}-$ FDG is a nonspecific tracer for NETs, and its uptake is always low in well-differentiated NETs (Huang and McConathy, 2013b).

Knowledge about NETs uptake amine precursors led to the development of ${ }^{11} \mathrm{C}$-HTP and ${ }^{18} \mathrm{~F}$-FDOPA. ${ }^{11} \mathrm{C}$-HTP is useful for detecting small tumors and early recurrences, however, the 20 -min half-life of ${ }^{11} \mathrm{C}$ limits the wide clinical use of ${ }^{11} \mathrm{C}-\mathrm{HTP}$ (Oberg and Castellano, 2011; Toumpanakis et al., 2014).

NETs increase activity of L-DOPA decarboxylase, so they show a high accumulation of ${ }^{18}$ FDOPA (Jager et al., 2008). ${ }^{18}$ F-FDOPA is a favorable AA tracer for diagnosing NETs with high accuracy, such as pheochromocytomas (Figure 6) (Wong et al., 2011), pancreatic pheochromocytoma and insulinomas, and for staging carcinoids (Koopmans et al., 2006; Timmers et al., 2007; Huang and McConathy, 2013b). Additionally, ${ }^{18} \mathrm{~F}$-FDOPA is a highly sensitive marker in patients with functional carcinoid tumors and has low sensitivity for malignant NETs, such as medullary thyroid cancer and pancreatic islet cell tumors (Weisbrod et al., 2012).

One study compared ${ }^{11} \mathrm{C}$-HTP PET and ${ }^{18} \mathrm{~F}$-FDOPA PET in patients with gastrointestinal-NET and pancreatic-NET. ${ }^{18} \mathrm{~F}-$ FDOPA was found to be more sensitive than ${ }^{11} \mathrm{C}-\mathrm{HTP}$ (98 vs. $89 \%$, respectively) for gastrointestinal-NET. However, for pancreatic-NET, the result was opposite ( $80 \mathrm{vs.} 96 \%$, respectively) (Orlefors et al., 1998; Toumpanakis et al., 2014).

\section{Prostate Cancers}

Prostate cancer is a complex and biologically heterogeneous tumor, which is the second leading cause of cancer-related death in the United States and Europe (Huang and McConathy, 2013b). ${ }^{18} \mathrm{~F}$-FDG is not an adequate tracer for differentiating prostate cancer, benign hyperplasia lesion and normal prostate (Picchio et al., 2015), and it is not useful for initial staging and is of limited utility in the clinical setting of biochemical failure after prior definitive therapy for primary cancer (Jadvar, 2016). ${ }^{11} \mathrm{C}$ MET is a helpful tracer for imaging the prostate in patients with increased PSA levels (Toth et al., 2005; Jana and Blaufox, 2006). Short dynamic scanning limits the wide clinical use of ${ }^{11} \mathrm{C}-\mathrm{MET}$ for imaging prostate cancer.

${ }^{18} \mathrm{~F}$-FACBC, an L-leucine analog, is a valuable tracer in the assessment of prostate cancer. Due to its low urinary excretion after injection (Figure 7), it has advantages in the imaging of prostate cancer (Schuster et al., 2007, 2011; Huang and 

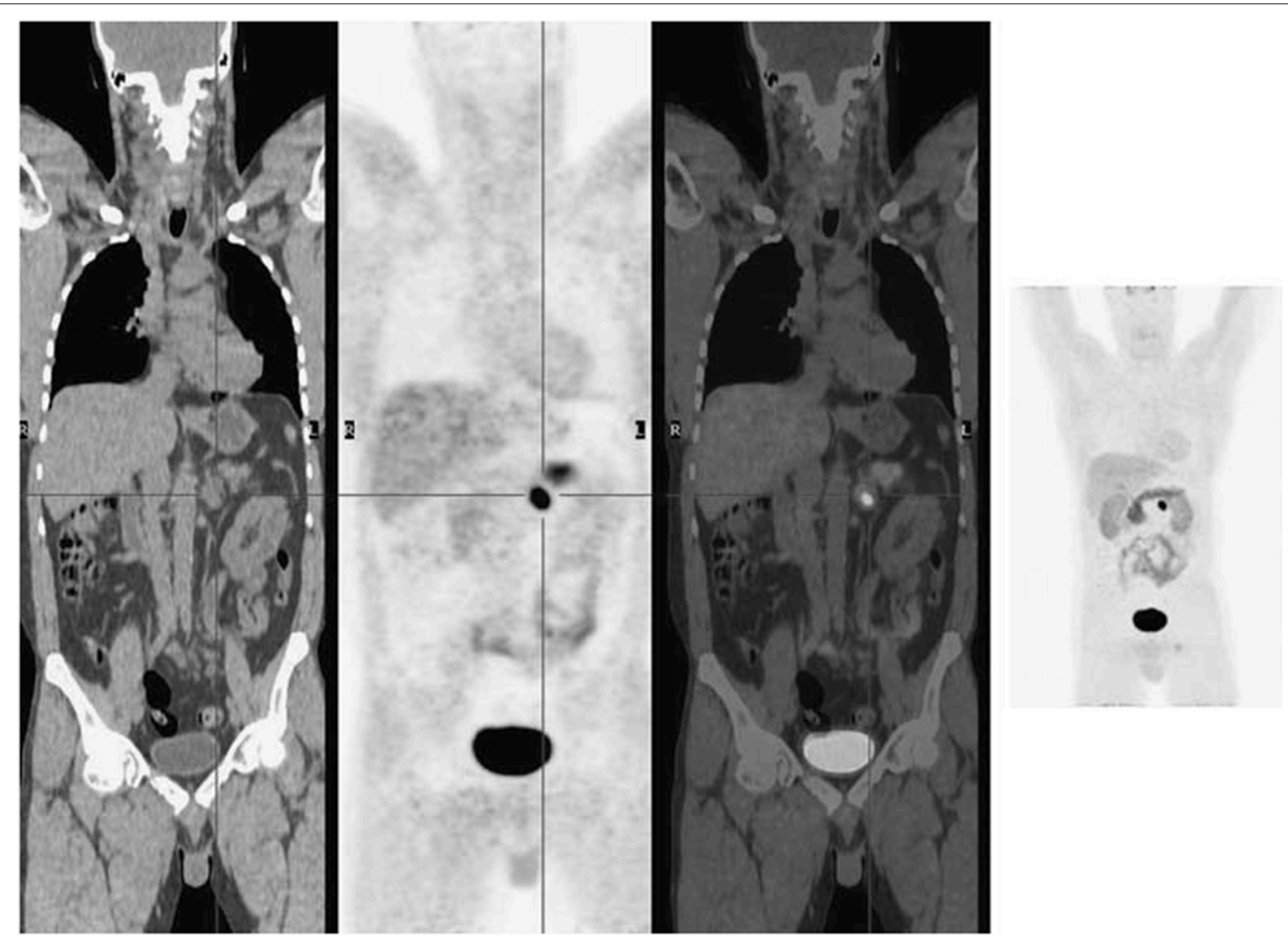

FIGURE 6 | ${ }^{18}$ F-FDOPA PET imaging illustrated a solitary left phaeochromocytoma. Left, coronal CT image; mid left, coronal PET image; mid right, coronal fused PET/CT image; right, maximum intensity projection image. This figure is reproduced with permission from Wong et al. (2011), Figure 9 ( ) by the Society of Journal of Nuclear Medicine Imaging, Inc.

McConathy, 2013b; Picchio et al., 2015). Prostate cancer, within the prostate or in pelvic lymph node metastases, can be detected using ${ }^{18}$ F-FACBC with high sensitivity and specificity (Schuster et al., 2011; Castellucci and Jadvar, 2012). The vitro uptake studies demonstrate that ${ }^{18} \mathrm{~F}$-FACBC is transported by LAT1 and ASCT2 in prostate cancer cell lines (Oka et al., 2012). More studies are needed to evaluate this radiotracer in the clinical management of men with prostate cancer (Schuster et al., 2011). ${ }^{18} \mathrm{~F}-\mathrm{FACPC}$, as an analog of ${ }^{18} \mathrm{~F}$-FACBC, is a helpful tracer for imaging prostate cancer, but ${ }^{18} \mathrm{~F}$-FACPC is not a good tracer for imaging pelvic lymph node metastases compared to ${ }^{18} \mathrm{~F}$-FACBC (Savir-Baruch et al., 2011).

\section{Other Tumors}

In maxillofacial tumors, the sensitivity of ${ }^{18} \mathrm{~F}$-FAMT is higher than that of ${ }^{18} \mathrm{~F}$-FDG, demonstrating that the accurate diagnosis of maxillofacial tumors is possible with ${ }^{18} \mathrm{~F}$-FAMT (Miyakubo et al., 2007).

Head and neck cancer can be imaged with ${ }^{11} \mathrm{C}$-MeAIB. ${ }^{11} \mathrm{C}$ MeAIB shows active and rapid transport into tumor tissues and salivary glands (Sutinen et al., 2003). ${ }^{11} \mathrm{C}-\mathrm{MeAIB}$ is also helpful in the differential diagnosis of pulmonary and mediastinal mass lesions (Nishii et al., 2013). ${ }^{18}$ F-D-FMT (BAY 86-9596), a derivative of ${ }^{18} \mathrm{~F}$-labeled tyrosine and is transported via the system L transporter 1 (LAT-1), showed a lower sensitivity but higher specificity for ${ }^{18} \mathrm{~F}$-D-FMT than ${ }^{18} \mathrm{~F}$-FDG in patients with NSCLC and head and neck squamous cell cancer and (Burger et al., 2014).

4-borono-2- ${ }^{18}$ F-fluoro-phenylalanine $\quad\left({ }^{18} \mathrm{~F}-\mathrm{FBPA}\right)$ was developed to predict ${ }^{10} \mathrm{~B}$ concentrations, presumably after administration of boron-containing drug for neutron-capture therapy (BNCT) (Wang et al., 2004; Menichetti et al., 2009; Tani et al., 2014). Studies showed that ${ }^{18}$ F-FBPA, was transported by system L, could evaluate BPA uptake in tumors for screening candidates for BNCT (Havu-Auren et al., 2007; Menichetti et al., 2009; Yoshimoto et al., 2013). However, the inconsistent result was showed that ${ }^{18} \mathrm{~F}$-FDG might be an effective tracer prior to ${ }^{18} \mathrm{~F}-\mathrm{FBPA}$ for screening patients with head and neck cancer for treatment with BNCT (Tani et al., 2014; Kobayashi et al., 2016).

\section{CONCLUSION AND PROSPECTS}

AA PET tracers can overcome the shortcomings of ${ }^{18} \mathrm{~F}-\mathrm{FDG}$ and provide more information for imaging tumors. Uptake mechanism of AA PET tracers involves protein synthesis or AA transport. For PET imaging, AA transport tracers appear more 
A

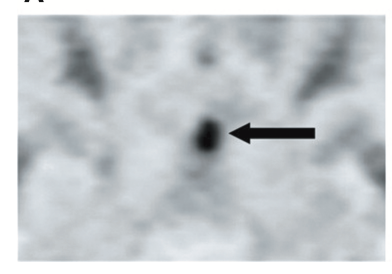

B

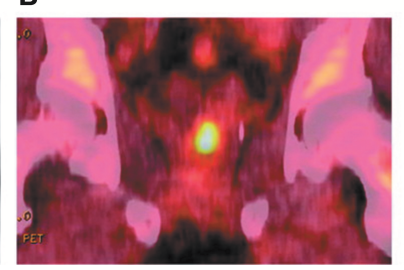

C

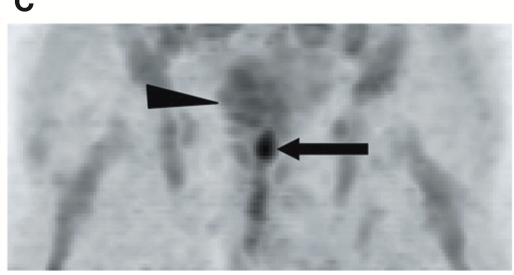

FIGURE 7 | ${ }^{18}$ F-FACBC PET images of a 71-year-old man with biopsy-proven prostate bed recurrence. (A) Coronal PET and (B) coronal fused PET/CT image illustrated the recurrent tumor extending toward left seminal vesicle (arrow in A). (C) Maximum-intensity-projection image at 20 min illustrated high uptake in prostate bed (arrow) with little bladder excretion (arrowhead). This figure is reproduced with permission from Schuster et al. (2007), Figure 4 (c) by the Society of Journal of Nuclear Medicine, Inc.

valuable than protein synthesis tracers in clinical applications. Targeting AA transporter system A, ASC, $\mathrm{L}$ and $\mathrm{X}_{\mathrm{C}^{-}}$, have been used in the clinical imaging of the biological behaviors of various tumors. Transporter system $\mathrm{L}$ has been a major focus of tracer development for imaging tumors (such as ${ }^{11} \mathrm{C}$-MET, ${ }^{18} \mathrm{~F}-\mathrm{FET}$, ${ }^{18} \mathrm{~F}$-FDOPA) and has also led to several AA tracers that are effective for imaging neuroendocrine tumors ( ${ }^{18} \mathrm{~F}$-FDOPA) and prostate cancer ( $\left.{ }^{18} \mathrm{~F}-\mathrm{FACBC}\right)$ (Huang and McConathy, 2013a). ${ }^{18}$ F-FSPG (BAY 94-9392), which is specific for system $\mathrm{X}_{\mathrm{C}^{-}}$ transporters (Koglin et al., 2011; Smolarz et al., 2013a), has been used for imaging patients with hepatocellular carcinoma (Baek et al., 2013), NSCLC (Smolarz et al., 2013a) and breast cancer (Chopra, 2004; Baek et al., 2012). Recently, new ${ }^{18}$ F-labeled branched-chain AAs have been developed that target cationic AA transporter and excitatory $\mathrm{AA}$ transporters $\mathrm{X}_{\mathrm{AG}^{-}}$, which are potential targets of AA PET tracers for tumor imaging. O-2((2$[(18) \mathrm{F}]$ fluoroethyl)methylamino)ethyltyrosine $\left({ }^{18} \mathrm{~F}\right.$-FMAET $)$ is specific for cationic AA transporter (Chiotellis et al., 2014). BAY 85-8050, a glutamate derivative, is specific for transport system $\mathrm{X}_{\mathrm{C}^{-}}$and systems $\mathrm{X}_{\mathrm{AG}^{-}}$, which is used to study healthy volunteers (Krasikova et al., 2011; Ploessl et al., 2012).

Besides branched-chain AAs, novel $N$-substituted labeled AAs and AA mimetics, have also been developed. ${ }^{18}$ F-FPGLU is $N$ methylsubstitutebeled amino glutamic acid as a potential AA tracer for PET imaging of transporter $\mathrm{X}_{\mathrm{AG}^{-}}$and $\mathrm{X}_{\mathrm{C}^{-}}$in tumor, and can be used for clinical tumor imaging in the near future. ${ }^{18} \mathrm{~F}$ $\mathrm{Phe}_{-\mathrm{BF}_{3}}$ (an exotic replacement of the carboxylate with $-\mathrm{BF}_{3}$ ) is a new class of AA mimetics-boramino acid tracer for PET imaging of transporter LAT1 in tumor, with specific accumulation in U87MG xenografts and low uptake in normal brain and an inflammatory region (Liu et al., 2015). Also, synthesis of novel AAs with conformationally constrained side chains will lead to developing a series of new radiolabeled AA mimetics for imaging disease, with good prospect (Mollica et al., 2010, 2012; Stefanucci et al., 2011; Way et al., 2014).

\section{REFERENCES}

Aiko, Y., Askew, D. J., Aramaki, S., Myoga, M., Tomonaga, C., Hachisuga, T., et al. (2014). Differential levels of amino acid transporters System L and ASCT2,
Novel radiolabeling techniques are developing for radiosynthesis of AA PET tracers, resulting in routine high-dose production of AA tracers for clinical PET imaging. Recently, the no-carrier-added (NCA) enantioselective synthesis using a chiral phase-transfer catalyst has been used for automated synthesis of NCA ${ }^{18}$ F-FDOPA with the Curie Level (Libert et al., 2013), and simple and efficient two-step synthesis of ${ }^{18}$ F-FDOPA with short synthesis times can supply adequate radioactivity for clinical imaging (Tredwell et al., 2014). Thus, ${ }^{18}$ F-FDOPA is easily available and will become widely used AA PET tracer for the detection of brain tumors, neuroendocrine tumors, Parkinson's disease (PD), and mental illness (Darcourt et al., 2014; Eggers et al., 2014; Li et al., 2014). Simple and practical click reaction and ${ }^{68} \mathrm{Ga}$ labeling methods are also used for preparing new AA tracers for imaging tumors, which will further boost translational application of AA tracers in clinics.

\section{AUTHOR CONTRIBUTIONS}

GT is the corresponding author for summarize amino acids PET tracers and the future about amino acids PET. He also reviewed this paper. AS searched literature and wrote the manuscript. XL searched literature and drew the figure and table.

\section{ACKNOWLEDGMENTS}

This work was supported in part by the National Natural Science Foundation of China (No. 81571704, No. 81371584, No. 81671719), the Science and Technology Foundation of Guangdong Province (No. 2014A020210008, No. 2013B021800264, No. 2016B090920087, No. 2013B010404018), the Science and Technology Planning Project Foundation of Guangzhou (No.201504301345364, No. 201510010145, No.201604020169), and the Natural Science Foundation of Guangdong Province (No. 2015A030313067). and the mTOR protein in placenta of preeclampsia and IUGR. BMC Pregnancy Childbirth 14:181. doi: 10.1186/1471-2393-14-181

Awasthi, V., Pathuri, G., Agashe, H. B., and Gali, H. (2011). Synthesis and in vivo evaluation of $\mathrm{p}-18 \mathrm{~F}$-Fluorohippurate as a new radiopharmaceutical 
for assessment of renal function by PET. J. Nucl. Med. 52, 147-153. doi: 10.2967/jnumed.110.075895

Babu, E., Kanai, Y., Chairoungdua, A., Kim, D. K., Iribe, Y., Tangtrongsup, S., et al. (2003). Identification of a novel system $\mathrm{L}$ amino acid transporter structurally distinct from heterodimeric amino acid transporters. J. Biol. Chem. 278, 43838-43845. doi: 10.1074/jbc.M305221200

Baek, S., Choi, C. M., Ahn, S. H., Lee, J. W., Gong, G., Ryu, J. S., et al. (2012). Exploratory clinical trial of (4S)-4-(3-[18F]fluoropropyl)-L-glutamate for imaging $\mathrm{xC}$ - transporter using positron emission tomography in patients with non-small cell lung or breast cancer. Clin. Cancer Res. 18, 5427-5437. doi: 10.1158/1078-0432.CCR-12-0214

Baek, S., Mueller, A., Lim, Y. S., Lee, H. C., Lee, Y. J., Gong, G., et al. (2013). (4S)-4-(3-18F-fluoropropyl)-L-glutamate for imaging of $\mathrm{xC}$ transporter activity in hepatocellular carcinoma using PET: preclinical and exploratory clinical studies. J. Nucl. Med. 54, 117-123. doi: 10.2967/jnumed.112.1 08704

Baker, D. A., Shen, H., and Kalivas, P. W. (2002). Cystine/glutamate exchange serves as the source for extracellular glutamate: modifications by repeated cocaine administration. Amino Acids 23, 161-162. doi: 10.1007/s00726-001-0122-6

Beuthien-Baumann, B., Bredow, J., Burchert, W., Füchtner, F., Bergmann, R., Alheit, H. D., et al. (2003). 3-O-methyl-6-[18F]fluoro-L-DOPA and its evaluation in brain tumour imaging. Eur. J. Nucl. Med. Mol. Imaging 30, 1004-1008. doi: 10.1007/s00259-003-1205-2

Bhutia, Y. D., Babu, E., Ramachandran, S., and Ganapathy, V. (2015). Amino Acid transporters in cancer and their relevance to "glutamine addiction": novel targets for the design of a new class of anticancer drugs. Cancer Res. 75, 1782-1788. doi: 10.1158/0008-5472.CAN-14-3745

Bianchi, M. G., Bardelli, D., Chiu, M., and Bussolati, O. (2014). Changes in the expression of the glutamate transporter EAAT3/EAAC1 in health and disease. Cell. Mol. Life Sci. 71, 2001-2015. doi: 10.1007/s00018-0131484-0

Bouchelouche, K., and Choyke, P. L. (2015). PET/Computed tomography in renal, bladder, and testicular cancer. PET Clin. 10, 361-374. doi: $10.1016 /$ j.cpet.2015.03.002

Bröer, S. (2014). The SLC38 family of sodium-amino acid co-transporters. Pflugers Arch. 466, 155-172. doi: 10.1007/s00424-013-1393-y

Burger, I. A., Zitzmann-Kolbe, S., Pruim, J., Friebe, M., Graham, K., Stephens, A., et al. (2014). First clinical results of (D)-18F-Fluoromethyltyrosine (BAY 86-9596) PET/CT in patients with non-small cell lung cancer and head and neck squamous cell carcinoma. J. Nucl. Med. 55, 1778-1785. doi: 10.2967/jnumed.114.140699

Bussolati, O., Uggeri, J., Belletti, S., Dall'Asta, V., and Gazzola, G. C. (1996). The stimulation of $\mathrm{Na}, \mathrm{K}, \mathrm{Cl}$ cotransport and of system A for neutral amino acid transport is a mechanism for cell volume increase during the cell cycle. FASEB J. 10, 920-926.

Castagna, M., Shayakul, C., Trotti, D., Sacchi, V. F., Harvey, W. R., and Hediger, M. A. (1997). Molecular characteristics of mammalian and insect amino acid transporters: implications for amino acid homeostasis. J. Exp. Biol. 200(Pt 2), 269-286.

Castellucci, P., and Jadvar, H. (2012). PET/CT in prostate cancer: non-choline radiopharmaceuticals. Q. J. Nucl. Med. Mol. Imaging 56, 367-374.

Ceyssens, S., Van Laere, K., de Groot, T., Goffin, J., Bormans, G., and Mortelmans, L. (2006). [11C]methionine PET, histopathology, and survival in primary brain tumors and recurrence. AJNR Am. J. Neuroradiol. 27, 1432-1437.

Chen, W., Silverman, D. H., Delaloye, S., Czernin, J., Kamdar, N., Pope, W., et al. (2006). 18F-FDOPA PET imaging of brain tumors: comparison study with $18 \mathrm{~F}-$ FDG PET and evaluation of diagnostic accuracy. J. Nucl. Med. 47, 904-911. doi: 10.3410/f.30526.487028

Chiotellis, A., Müller, A., Weyermann, K., Leutwiler, D. S., Schibli, R., Ametamey, S. M., et al. (2014). Synthesis and preliminary biological evaluation of O-2((2-[(18)F]fluoroethyl)methylamino)ethyltyrosine ([(18)F]FEMAET) as a potential cationic amino acid PET tracer for tumor imaging. Amino Acids 46, 1947-1959. doi: 10.1007/s00726-014-1754-7

Chopra, A. (2004). "(4S)-4-(3-[18F]Fluoropropyl)-l-glutamate," in Molecular Imaging and Contrast Agent Database (MICAD) (Bethesda, MD).

Christensen, H. N. (1990). Role of amino acid transport and countertransport in nutrition and metabolism. Physiol. Rev. 70, 43-77.
Dall'Asta, V., Gazzola, G. C., Franchi-Gazzola, R., Bussolati, O., Longo, N., and Guidotti, G. G. (1983). Pathways of L-glutamic acid transport in cultured human fibroblasts. J. Biol. Chem. 258, 6371-6379.

Darcourt, J., Schiazza, A., Sapin, N., Dufour, M., Ouvrier, M. J., Benisvy, D., et al. (2014). 18F-FDOPA PET for the diagnosis of parkinsonian syndromes. Q. J. Nucl. Med. Mol. Imaging 58, 355-365.

de Boer, J. R., Pruim, J., van der Laan, B. F., Que, T. H., Willemsen, A. T., Albers, F. W., et al. (2003). L-1-11C-tyrosine PET in patients with laryngeal carcinomas: comparison of standardized uptake value and protein synthesis rate. J. Nucl. Med. 44, 341-346.

Deng, H., Tang, X., Wang, H., Tang, G., Wen, F., Shi, X., et al. (2011). S-11Cmethyl-L-cysteine: a new amino acid PET tracer for cancer imaging. J. Nucl. Med. 52, 287-293. doi: 10.2967/jnumed.110.081349

De Vis, K., Schelstraete, K., Deman, J., Vermeulen, F. L., Sambre, J., Goethals, P., et al. (1987). Clinical comparison of 11C-ACPC (aminocyclopentane carboxylic acid) and 13N-ammonia as tumour tracers. Acta Oncol. 26, 105-111. doi: $10.3109 / 02841868709091749$

Dunet, V., Rossier, C., Buck, A., Stupp, R., and Prior, J. O. (2012). Performance of 18F-fluoro-ethyl-tyrosine (18F-FET) PET for the differential diagnosis of primary brain tumor: a systematic review and Metaanalysis. J. Nucl. Med. 53, 207-214. doi: 10.2967/jnumed.111.096859

Eggers, C., Schwartz, F., Pedrosa, D. J., Kracht, L., and Timmermann, L. (2014). Parkinson's disease subtypes show a specific link between dopaminergic and glucose metabolism in the striatum. PLoS ONE 9:e96629. doi: 10.1371/journal.pone.0096629

Esslinger, C. S., Cybulski, K. A., and Rhoderick, J. F. (2005). Ngamma-aryl glutamine analogues as probes of the ASCT2 neutral amino acid transporter binding site. Bioorg. Med. Chem. 13, 1111-1118. doi: 10.1016/j.bmc.2004.11.028

Fuchs, B. C., and Bode, B. P. (2005). Amino acid transporters ASCT2 and LAT1 in cancer: partners in crime? Semin. Cancer Biol. 15, 254-266. doi: 10.1016/j.semcancer.2005.04.005

Fuchs, B. C., Finger, R. E., Onan, M. C., and Bode, B. P. (2007). ASCT2 silencing regulates mammalian target-of-rapamycin growth and survival signaling in human hepatoma cells. Am. J. Physiol. Cell Physiol. 293, C55-C63. doi: $10.1152 /$ ajpcell.00330.2006

Fueger, B. J., Czernin, J., Cloughesy, T., Silverman, D. H., Geist, C. L., Walter, M. A., et al. (2010). Correlation of 6-18F-fluoro-L-dopa PET uptake with proliferation and tumor grade in newly diagnosed and recurrent gliomas. J. Nucl. Med. 51, 1532-1538. doi: 10.2967/jnumed.110.078592

Galldiks, N., Dunkl, V., Stoffels, G., Hutterer, M., Rapp, M., Sabel, M., et al. (2015a). Diagnosis of pseudoprogression in patients with glioblastoma using O-(2-[18F]fluoroethyl)-L-tyrosine PET. Eur. J. Nucl. Med. Mol. Imaging 42, 685-695. doi: 10.1007/s00259-014-2959-4

Galldiks, N., Kracht, L. W., Burghaus, L., Thomas, A., Jacobs, A. H., Heiss, W. D., et al. (2006). Use of 11C-methionine PET to monitor the effects of temozolomide chemotherapy in malignant gliomas. Eur. J. Nucl. Med. Mol. Imaging 33, 516-524. doi: 10.1007/s00259-005-0002-5

Galldiks, N., Stoffels, G., Filss, C., Rapp, M., Blau, T., Tscherpel, C., et al. (2015b). The use of dynamic O-(2- ${ }^{18} \mathrm{~F}$-fluoroethyl)-l-tyrosine PET in the diagnosis of patients with progressive and recurrent glioma. Neuro Oncol. 17, 1293-1300. doi: 10.1093/neuonc/nov088

Glaudemans, A. W., Enting, R. H., Heesters, M. A., Dierckx, R. A., van Rheenen, R. W., Walenkamp, A. M., et al. (2013). Value of 11C-methionine PET in imaging brain tumours and metastases. Eur. J. Nucl. Med. Mol. Imaging 40, 615-635. doi: 10.1007/s00259-012-2295-5

Gulyás, B., and Halldin, C. (2012). New PET radiopharmaceuticals beyond FDG for brain tumor imaging. Q. J. Nucl. Med. Mol. Imaging 56, 173-190.

Hammermann, R., Brunn, G., and Racke, K. (2001). Analysis of the genomic organization of the human cationic amino acid transporters CAT-1, CAT-2 and CAT-4. Amino Acids 21, 211-219. doi: 10.1007/s007260170029

Hatakeyama, T., Kawai, N., Nishiyama, Y., Yamamoto, Y., Sasakawa, Y., Ichikawa, T., et al. (2008). 11C-methionine (MET) and 18F-fluorothymidine (FLT) PET in patients with newly diagnosed glioma. Eur. J. Nucl. Med. Mol. Imaging 35, 2009-2017. doi: 10.1007/s00259-008-0847-5

Havu-Aurén, K., Kiiski, J., Lehtio, K., Eskola, O., Kulvik, M., Vuorinen, V., et al. (2007). Uptake of 4-borono-2-[18F]fluoro-L-phenylalanine in sporadic and neurofibromatosis 2-related schwannoma and meningioma studied with PET. Eur. J. Nucl. Med. Mol. Imaging 34, 87-94. doi: 10.1007/s00259-006-0154-y 
He, S., Tang, G., Hu, K., Wang, H., Wang, S., Huang, T., et al. (2013). Radiosynthesis and biological evaluation of 5-(3-[18F]fluoropropyloxy)L-tryptophan for tumor PET imaging. Nucl. Med. Biol. 40, 801-807. doi: 10.1016/j.nucmedbio.2013.04.013

Howell, J. A., Matthews, A. D., Swanson, K. C., Harmon, D. L., and Matthews, J. C. (2001). Molecular identification of high-affinity glutamate transporters in sheep and cattle forestomach, intestine, liver, kidney, and pancreas. J. Anim. Sci. 79, 1329-1336. doi: 10.2527/2001.7951329x

Hu, K., Du, K., Tang, G., Yao, S., Wang, H., Liang, X., et al. (2014). Radiosynthesis and biological evaluation of $\mathrm{N}$-[18F]labeled glutamic acid as a tumor metabolic imaging tracer. PLoS ONE 9:e93262. doi: 10.1371/journal.pone.0093262

Hu, K. Z., Wang, H., Huang, T., Tang, G., Liang, X., He, S., et al. (2013). Synthesis and biological evaluation of N-(2-[(18)F]Fluoropropionyl)L-methionine for tumor imaging. Nucl. Med. Biol. 40, 926-932. doi: 10.1016/j.nucmedbio.2013.06.006

Huang, C., and McConathy, J. (2013a). Fluorine-18 labeled amino acids for oncologic imaging with positron emission tomography. Curr. Top. Med. Chem. 13, 871-891. doi: 10.2174/1568026611313080002

Huang, C., and McConathy, J. (2013b). Radiolabeled amino acids for oncologic imaging. J. Nucl. Med. 54, 1007-1010. doi: 10.2967/jnumed.112.113100

Huang, T., Tang, G., Wang, H., Nie, D., Tang, X., Liang, X., et al. (2015). Synthesis and preliminary biological evaluation of S-11C-methyl-D-cysteine as a new amino acid PET tracer for cancer imaging. Amino Acids 47, 719-727. doi: 10.1007/s00726-014-1899-4

Ishii, K., Ogawa, T., Hatazawa, J., Kanno, I., Inugami, A., Fujita, H., et al. (1993). High L-methyl-[11C]methionine uptake in brain abscess: a PET study. J. Comput. Assist. Tomogr. 17, 660-661. doi: 10.1097/00004728-199307000-00029

Ishiwata, K., Enomoto, K., Sasaki, T., Elsinga, P. H., Senda, M., Okazumi, S., et al. (1996). A feasibility study on L-[1-carbon-11]tyrosine and L-[methylcarbon-11]methionine to assess liver protein synthesis by PET. J. Nucl. Med. 37, 279-285

Ishiwata, K., Kubota, K., Murakami, M., Kubota, R., Sasaki, T., Ishii, S., et al. (1993). Re-evaluation of amino acid PET studies: can the protein synthesis rates in brain and tumor tissues be measured in vivo? J. Nucl. Med. 34, 1936-1943.

Ishiwata, K., Vaalburg, W., Elsinga, P. H., Paans, A. M., and Woldring, M. G. (1988). Comparison of L-[1-11C]methionine and L-methyl-[11C]methionine for measuring in vivo protein synthesis rates with PET. J. Nucl. Med. 29, 1419-1427.

Jadvar, H. (2016). PET of Glucose metabolism and cellular proliferation in prostate cancer. J. Nucl. Med. 57(Suppl. 3), 25S-29S. doi: 10.2967/jnumed.115.170704

Jager, P. L., Chirakal, R., Marriott, C. J., Brouwers, A. H., Koopmans, K. P., and Gulenchyn, K. Y. (2008). 6-L-18F-fluorodihydroxyphenylalanine PET in neuroendocrine tumors: basic aspects and emerging clinical applications. J. Nucl. Med. 49, 573-586. doi: 10.2967/jnumed.107.045708

Jager, P. L., Vaalburg, W., Pruim, J., de Vries, E. G., Langen, K. J., and Piers, D. A. (2001). Radiolabeled amino acids: basic aspects and clinical applications in oncology. J. Nucl. Med. 42, 432-445.

Jana, S., and Blaufox, M. D. (2006). Nuclear medicine studies of the prostate, testes, and bladder. Semin. Nucl. Med. 36, 51-72. doi: 10.1053/j.semnuclmed.2005.09.001

Jansen, N. L., Suchorska, B., Wenter, V., Schmid-Tannwald, C., Todica, A., Eigenbrod, S., et al. (2015). Prognostic significance of dynamic 18F-FET PET in newly diagnosed astrocytic high-grade glioma. J. Nucl. Med. 56, 9-15. doi: 10.2967/jnumed.114.144675

Juhász, C., Dwivedi, S., Kamson, D. O., Michelhaugh, S. K., and Mittal, S. (2014). Comparison of amino acid positron emission tomographic radiotracers for molecular imaging of primary and metastatic brain tumors. Mol. Imaging 13, 1-16. doi: 10.2310/7290.2014.00015

Juhasz, C., Muzik, O., Chugani, D. C., Chugani, H. T., Sood, S., Chakraborty, P. K., et al. (2011). Differential kinetics of alpha-[(1)(1)C]methyl-Ltryptophan on PET in low-grade brain tumors. J. Neurooncol. 102, 409-415. doi: 10.1007/s11060-010-0327-1

Kaira, K., Sunose, Y., Ohshima, Y., Ishioka, N. S., Arakawa, K., Ogawa, T., et al. (2013). Clinical significance of L-type amino acid transporter 1 expression as a prognostic marker and potential of new targeting therapy in biliary tract cancer. BMC Cancer 13:482. doi: 10.1186/1471-2407-13-482

Kanai, Y., Clémençon, B., Simonin, A., Leuenberger, M., Lochner, M., Weisstanner, M., et al. (2013). The SLC1 high-affinity glutamate and neutral amino acid transporter family. Mol. Aspects Med. 34, 108-120. doi: 10.1016/j.mam.2013.01.001

Karunakaran, S., Ramachandran, S., Coothankandaswamy, V., Elangovan, S., Babu, E., Periyasamy-Thandavan, S., et al. (2011). SLC6A14 (ATB0,+) protein, a highly concentrative and broad specific amino acid transporter, is a novel and effective drug target for treatment of estrogen receptor-positive breast cancer. J. Biol. Chem. 286, 31830-31838. doi: 10.1074/jbc.M111.229518

Kobayashi, K., Kurihara, H., Watanabe, Y., Murakami, N., Inaba, K., Nakamura, S., et al. (2016). In vivo spatial correlation between (18)F-BPA and (18)FFDG uptakes in head and neck cancer. Appl. Radiat. Isot. 115, 138-146. doi: 10.1016/j.apradiso.2016.05.026

Koglin, N., Mueller, A., Berndt, M., Schmitt-Willich, H., Toschi, L., Stephens, A. W., et al. (2011). Specific PET Imaging of $\mathrm{x}(\mathrm{C})(-)$ transporter activity using a F-18-labeled glutamate derivative reveals a dominant pathway in tumor metabolism. Clin. Cancer Res. 17, 6000-6011. doi: 10.1158/1078-0432.CCR-11-0687

Koopmans, K. P., de Vries, E. G., Kema, I. P., Elsinga, P. H., Neels, O. C., Sluiter, W. J., et al. (2006). Staging of carcinoid tumours with 18F-DOPA PET: a prospective, diagnostic accuracy study. Lancet Oncol. 7, 728-734. doi: 10.1016/S1470-2045(06)70801-4

Krasikova, R. N., Kuznetsova, O. F., Fedorova, O. S., Belokon, Y. N., Maleev, V. I., Mu, L., et al. (2011). 4-[18F]fluoroglutamic acid (BAY 85-8050), a new amino acid radiotracer for PET imaging of tumors: synthesis and in vitro characterization. J. Med. Chem. 54, 406-410. doi: 10.1021/jm1 $01068 \mathrm{q}$

Langen, K. J., Hamacher, K., Weckesser, M., Floeth, F., Stoffels, G., Bauer, D., et al. (2006). O-(2-[18F]fluoroethyl)-L-tyrosine: uptake mechanisms and clinical applications. Nucl. Med. Biol. 33, 287-294. doi: 10.1016/j.nucmedbio.2006.01.002

Lau, E. W., Drummond, K. J., Ware, R. E., Drummond, E., Hogg, A., Ryan, G., et al. (2010). Comparative PET study using F-18 FET and F-18 FDG for the evaluation of patients with suspected brain tumour. J. Clin. Neurosci. 17, 43-49. doi: 10.1016/j.jocn.2009.05.009

Laverman, P., Boerman, O. C., Corstens, F. H., and Oyen, W. J. (2002). Fluorinated amino acids for tumour imaging with positron emission tomography. Eur. J. Nucl. Med. Mol. Imaging 29, 681-690. doi: 10.1007/s00259-001-0716-y

Lebarre, J., Crouzel, C., and Donie, P. (1991). Preliminary results on the biosynthesis of $[11 \mathrm{C}]$ phenylalanine using a photosynthetic bacterium. Acta Radiol. Suppl. 376, 109.

Lewerenz, J., Hewett, S. J., Huang, Y., Lambros, M., Gout, P. W., Kalivas, P. W., et al. (2013). The cystine/glutamate antiporter system $\mathrm{x}(\mathrm{c})(-)$ in health and disease: from molecular mechanisms to novel therapeutic opportunities. Antioxid. Redox Signal. 18, 522-555. doi: 10.1089/ars.2011.4391

Lewerenz, J., Maher, P., and Methner, A. (2012). Regulation of xCT expression and system x (c) (-) function in neuronal cells. Amino Acids 42, 171-179. doi: 10.1007/s00726-011-0862-x

Lewis, D. Y., Soloviev, D., and Brindle, K. M. (2015). Imaging tumor metabolism using positron emission tomography. Cancer J. 21, 129-136. doi: 10.1097/PPO.0000000000000105

Li, C. T., Palotti, M., Holden, J. E., Oh, J., Okonkwo, O., Christian, B. T., et al. (2014). A dual-tracer study of extrastriatal 6-[18F]fluoro-m-tyrosine and 6-[18F]-fluoro-L-dopa uptake in Parkinson's disease. Synapse 68, 325-331. doi: $10.1002 /$ syn. 21745

Li, R., Younes, M., Frolov, A., Wheeler, T. M., Scardino, P., Ohori, M., et al. (2003). Expression of neutral amino acid transporter ASCT2 in human prostate. Anticancer Res. 23, 3413-3418.

Libert, L. C., Franci, X., Plenevaux, A. R., Ooi, T., Maruoka, K., Luxen, A. J., et al. (2013). Production at the Curie level of no-carrier-added 6-18F-fluoro-L-dopa. J. Nucl. Med. 54, 1154-1161. doi: 10.2967/jnumed.112.112284

Lieberman, B. P., Ploessl, K., Wang, L., Qu, W., Zha, Z., Wise, D. R., et al. (2011). PET imaging of glutaminolysis in tumors by $18 \mathrm{~F}-(2 \mathrm{~S}, 4 \mathrm{R}) 4$-fluoroglutamine. $J$. Nucl. Med. 52, 1947-1955. doi: 10.2967/jnumed.111.093815

Liu, Z., Chen, H., Chen, K., Shao, Y., Kiesewetter, D. O., Niu, G., et al. (2015). Boramino acid as a marker for amino acid transporters. Sci. Adv. 1:e1500694. doi: 10.1126/sciadv.1500694

Lo, M., Wang, Y. Z., and Gout, P. W. (2008). The x(c)(-) cystine/glutamate antiporter: a potential target for therapy of cancer and other diseases. J. Cell. Physiol. 215, 593-602. doi: 10.1002/jcp.21366 
McConathy, J., and Goodman, M. M. (2008). Non-natural amino acids for tumor imaging using positron emission tomography and single photon emission computed tomography. Cancer Metastasis Rev. 27, 555-573. doi: 10.1007/s10555-008-9154-7

McConathy, J., Yu, W., Jarkas, N., Seo, W., Schuster, D. M., and Goodman, M. M. (2012). Radiohalogenated nonnatural amino acids as PET and SPECT tumor imaging agents. Med. Res. Rev. 32, 868-905. doi: 10.1002/med.20250

Menichetti, L., Cionini, L., Sauerwein, W. A., Altieri, S., Solin, O., Minn, H., et al. (2009). Positron emission tomography and [18F]BPA: a perspective application to assess tumour extraction of boron in BNCT. Appl. Radiat. Isot. 67, S351-S354. doi: 10.1016/j.apradiso.2009.03.062

Minamimoto, R., Saginoya, T., Kondo, C., Tomura, N., Ito, K., Matsuo, Y., et al. (2015). Differentiation of brain tumor recurrence from post-radiotherapy necrosis with 11C-Methionine PET: visual assessment vs. quantitative assessment. PLoS ONE 10:e0132515. doi: 10.1371/journal.pone.0132515

Miyakubo, M., Oriuchi, N., Tsushima, Y., Higuchi, T., Koyama, K., Arai, K., et al. (2007). Diagnosis of maxillofacial tumor with L-3-[18f]-fluoro-alphamethyltyrosine (FMT) PET: a comparative study with FDG-PET. Ann. Nucl. Med. 21, 129-135. doi: 10.1007/BF03033991

Mollica, A., Feliciani, F., Stefanucci, A., Cacciatore, I., Cornacchia, C., Torino, D., et al. (2010). N-(tert)-butyloxycarbonyl)-beta,beta-cyclopentyl-cysteine (acetamidomethyl)-methyl ester for synthesis of novel peptidomimetic derivatives. Protein Pept. Lett. 17, 925-929. doi: 10.2174/092986610791306760

Mollica, A., Feliciani, F., Stefanucci, A., Fadeev, E. A., and Pinnen, F. (2012). (Acyloxy)alkoxy moiety as amino acids protecting group for the synthesis of (R,R)-2,7 diaminosuberic acid via RCM. Protein Pept. Lett. 19, 1245-1249. doi: 10.2174/092986612803521666

Mossine, A. V., Thompson, S., Brooks, A. F., Sowa, A. R., Miller, J. M., and Scott, P. J. (2016). Fluorine-18 patents (2009-2015). Part 2: new radiochemistry. Pharm. Pat. Anal. 5, 319-349. doi: 10.4155/ppa-2016-0028

Nakagawa, M., Kuwabara, Y., Sasaki, M., Koga, H., Chen, T., Kaneko, O., et al. (2002). 11C-methionine uptake in cerebrovascular disease: a comparison with 18F-fDG PET and 99mTc-HMPAO SPECT. Ann. Nucl. Med. 16, 207-211. doi: 10.1007/BF02996302

Nariai, T., Tanaka, Y., Wakimoto, H., Aoyagi, M., Tamaki, M., Ishiwata, K., et al. (2005). Usefulness of L-[methyl-11C] methionine-positron emission tomography as a biological monitoring tool in the treatment of glioma. J. Neurosurg. 103, 498-507. doi: 10.3171/jns.2005.103.3.0498

Nedergaard, M. K., Kristoffersen, K., Michaelsen, S. R., Madsen, J., Poulsen, H. S., Stockhausen, M. T., et al. (2014). The use of longitudinal 18FFET MicroPET imaging to evaluate response to irinotecan in orthotopic human glioblastoma multiforme xenografts. PLoS ONE 9:e100009. doi: 10.1371/journal.pone.0100009

Nel, M. J., Woodiwiss, A. J., and Candy, G. P. (2012). Modeling of cellular arginine uptake by more than one transporter. J. Membr. Biol. 245, 1-13. doi: 10.1007/s00232-011-9408-0

Nishii, R., Higashi, T., Kagawa, S., Kishibe, Y., Takahashi, M., Yamauchi, H., et al. (2013). Diagnostic usefulness of an amino acid tracer, alpha-[N-methyl-(11)C]methylaminoisobutyric acid ((11)C-MeAIB), in the PET diagnosis of chest malignancies. Ann. Nucl. Med. 27, 808-821. doi: 10.1007/s12149-013-0750-4

Niyazi, M., Jansen, N., Ganswindt, U., Schwarz, S. B., Geisler, J., Schnell, O., et al. (2012). Re-irradiation in recurrent malignant glioma: prognostic value of [18F]FET-PET. J. Neurooncol. 110, 389-395. doi: 10.1007/s11060-0120980-7

Oberg, K., and Castellano, D. (2011). Current knowledge on diagnosis and staging of neuroendocrine tumors. Cancer Metastasis Rev. 30(Suppl. 1), 3-7. doi: 10.1007/s10555-011-9292-1

Ogihara, K., Naya, Y., Sato, R., Onda, K., and Ochiai, H. (2015). Analysis of L-type amino acid transporter in canine hepatocellular carcinoma. J. Vet. Med. Sci. 77, 527-534. doi: 10.1292/jvms.14-0392

Oka, S., Okudaira, H., Yoshida, Y., Schuster, D. M., Goodman, M. M., and Shirakami, Y. (2012). Transport mechanisms of trans-1-amino-3-fluoro[1(14)C]cyclobutanecarboxylic acid in prostate cancer cells. Nucl. Med. Biol. 39, 109-119. doi: 10.1016/j.nucmedbio.2011.06.008

Olivero, W. C., Dulebohn, S. C., and Lister, J. R. (1995). The use of PET in evaluating patients with primary brain tumours: is it useful? J. Neurol. Neurosurg. Psychiatr. 58, 250-252. doi: 10.1136/jnnp.58.2.250
Orlefors, H., Sundin, A., Ahlström, H., Bjurling, P., Bergström, M., Lilja, A., et al. (1998). Positron emission tomography with 5hydroxytryprophan in neuroendocrine tumors. J. Clin. Oncol. 16, 2534-2541. doi: 10.1200/JCO.1998.16.7.2534

Paans, A. M., Pruim, J., van Waarde, A., Willemsen, A. T., and Vaalburg, W. (1996). Radiolabelled-tyrosine for the measurement of protein synthesis rate in vivo by positron emission tomography. Baillieres. Clin. Endocrinol. Metab. 10, 497-510. doi: 10.1016/S0950-351X(96)80666-5

Pafundi, D. H., Laack, N. N., Youland, R. S., Parney, I. F., Lowe, V. J., Giannini, C., et al. (2013). Biopsy validation of 18F-DOPA PET and biodistribution in gliomas for neurosurgical planning and radiotherapy target delineation: results of a prospective pilot study. Neuro Oncol. 15, 1058-1067. doi: 10.1093/neuonc/not002

Palacín, M., Estévez, R., Bertran, J., and Zorzano, A. (1998). Molecular biology of mammalian plasma membrane amino acid transporters. Physiol. Rev. 78, 969-1054.

Pan, M., Wasa, M., and Souba, W. W. (1995a). Protein kinase C activation inhibits glutamate transport by endothelial cells. J. Surg. Res. 58, 630-635. doi: 10.1006/jsre.1995.1099

Pan, M., Wasa, M., and Souba, W. W. (1995b). Tumor necrosis factor stimulates system XAG- transport activity in human endothelium. J. Surg. Res. 58, 659-664. doi: 10.1006/jsre.1995.1104

Picchio, M., Mapelli, P., Panebianco, V., Castellucci, P., Incerti, E., Briganti, A., et al. (2015). Imaging biomarkers in prostate cancer: role of PET/CT and MRI. Eur. J. Nucl. Med. Mol. Imaging 42, 644-655. doi: 10.1007/s00259-014-2982-5

Ploessl, K., Wang, L., Lieberman, B. P., Qu, W., and Kung, H. F. (2012). Comparative evaluation of 18F-labeled glutamic acid and glutamine as tumor metabolic imaging agents. J. Nucl. Med. 53, 1616-1624. doi: 10.2967/jnumed.111.101279

Popperl, G., Kreth, F. W., Mehrkens, J. H., Herms, J., Seelos, K., Koch, W., et al. (2007). FET PET for the evaluation of untreated gliomas: correlation of FET uptake and uptake kinetics with tumour grading. Eur. J. Nucl. Med. Mol. Imaging 34, 1933-1942. doi: 10.1007/s00259-007-0534-y

Powles, T., Murray, I., Brock, C., Oliver, T., and Avril, N. (2007). Molecular positron emission tomography and PET/CT imaging in urological malignancies. Eur. Urol. 51, 1511-1520. discussion: 1520-1511. doi: 10.1016/j.eururo.2007.01.061

Prenant, C., Theobald, A., Haberkorn, U., Bellemann, M. E., Weber, K., and Oberdorfer, F. (1996). Feasibility of labeled alpha-acetamidoaminoisobutyric acid as new tracer compound for kinetic labeling of neutral amino acid transport: preparation of alpha-(N-[1-11C]acetyl)- and alpha-(N-[1-14C]acetyl)-aminoisobutyric acid. Nucl. Med. Biol. 23, 359-363. doi: 10.1016/0969-8051(96)00016-9

Qu, W., Oya, S., Lieberman, B. P., Ploessl, K., Wang, L., Wise, D. R., et al. (2012). Preparation and characterization of L-[5-11C]-glutamine for metabolic imaging of tumors. J. Nucl. Med. 53, 98-105. doi: 10.2967/jnumed.111.093831

Rau, F. C., Weber, W. A., Wester, H. J., Herz, M., Becker, I., Kruger, A., et al. (2002). O-(2-[(18)F]Fluoroethyl)- L-tyrosine (FET): a tracer for differentiation of tumour from inflammation in murine lymph nodes. Eur. J. Nucl. Med. Mol. Imaging 29, 1039-1046. doi: 10.1007/s00259-002-0821-6

Reissner, K. J., and Kalivas, P. W. (2010). Using glutamate homeostasis as a target for treating addictive disorders. Behav. Pharmacol. 21, 514-522. doi: 10.1097/FBP.0b013e32833d41b2

Rioja, J., Rodriguez-Fraile, M., Lima-Favaretto, R., Rincon-Mayans, A., Penuelas-Sanchez, I., Zudaire-Bergera, J. J., et al. (2010). Role of positron emission tomography in urological oncology. BJU Int. 106, 1578-1593. doi: 10.1111/j.1464-410X.2010.09510.x

Rosilio, C., Nebout, M., Imbert, V., Griessinger, E., Neffati, Z., Benadiba, J., et al. (2015). L-type amino-acid transporter 1 (LAT1): a therapeutic target supporting growth and survival of T-cell lymphoblastic lymphoma/T-cell acute lymphoblastic leukemia. Leukemia 29, 1253-1266. doi: 10.1038/leu.2014.338

Savir-Baruch, B., Schuster, D. M., Jarkas, N., Master, V. A., Nieh, P. T., Halkar, R. K., et al. (2011). Pilot evaluation of anti-1-amino-2-[18F] fluorocyclopentane-1carboxylic acid (anti-2-[18F] FACPC) PET-CT in recurrent prostate carcinoma. Mol. Imaging Biol. 13, 1272-1277. doi: 10.1007/s11307-010-0445-3

Schulte, M. L., Dawson, E. S., Saleh, S. A., Cuthbertson, M. L., and Manning, H. C. (2015). 2-Substituted Ngamma-glutamylanilides as novel probes of 
ASCT2 with improved potency. Bioorg. Med. Chem. Lett. 25, 113-116. doi: 10.1016/j.bmcl.2014.10.098

Schuster, D. M., Savir-Baruch, B., Nieh, P. T., Master, V. A., Halkar, R. K., Rossi, P. J., et al. (2011). Detection of recurrent prostate carcinoma with anti-1-amino3-18F-fluorocyclobutane-1-carboxylic acid PET/CT and 111In-capromab pendetide SPECT/CT. Radiology 259, 852-861. doi: 10.1148/radiol.111 02023

Schuster, D. M., Votaw, J. R., Nieh, P. T., Yu, W., Nye, J. A., Master, V., et al. (2007). Initial experience with the radiotracer anti-1-amino-3- ${ }^{18} \mathrm{~F}$-fluorocyclobutane1-carboxylic acid with PET/CT in prostate carcinoma. J. Nucl. Med. 48, 56-63.

Shotwell, M. A., Kilberg, M. S., and Oxender, D. L. (1983). The regulation of neutral amino acid transport in mammalian cells. Biochim. Biophys. Acta 737, 267-284. doi: 10.1016/0304-4157(83)90003-5

Smolarz, K., Krause, B. J., Graner, F. P., Wagner, F. M., Hultsch, C., BacherStier, C., et al. (2013a). (S)-4-(3-18F-fluoropropyl)-L-glutamic acid: an 18Flabeled tumor-specific probe for PET/CT imaging-dosimetry. J. Nucl. Med. 54, 861-866. doi: 10.2967/jnumed.112.112581

Smolarz, K., Krause, B. J., Graner, F. P., Wagner, F. M., Wester, H. J., Sell, T., et al. (2013b). Biodistribution and radiation dosimetry in healthy volunteers of a novel tumour-specific probe for PET/CT imaging: BAY 85-8050. Eur. J. Nucl. Med. Mol. Imaging 40, 1861-1868. doi: 10.1007/s00259-013-2502-z

Sonoda, Y., Kumabe, T., Takahashi, T., Shirane, R., and Yoshimoto, T. (1998). Clinical usefulness of 11C-MET PET and 201T1 SPECT for differentiation of recurrent glioma from radiation necrosis. Neurol. Med. Chir. (Tokyo) 38, 342-347. discussion: 347-348. doi: 10.2176/nmc.38.342

Stefanucci, A., Pinnen, F., Feliciani, F., Cacciatore, I., Lucente, G., and Mollica, A. (2011). Conformationally constrained histidines in the design of peptidomimetics: strategies for the chi-space control. Int. J. Mol. Sci. 12, 2853-2890. doi: 10.3390/ijms12052853

Stober, B., Tanase, U., Herz, M., Seidl, C., Schwaiger, M., and SenekowitschSchmidtke, R. (2006). Differentiation of tumour and inflammation: characterisation of [methyl-3H]methionine (MET) and O-(2[18F]fluoroethyl)-L-tyrosine (FET) uptake in human tumour and inflammatory cells. Eur. J. Nucl. Med. Mol. Imaging 33, 932-939. doi: 10.1007/s00259-005-0047-5

Stoffels, G., Pauleit, D., Haas, R., Kobbe, G., Salber, D., Hamacher, K., et al. (2008). cis-4-[(18)F]-Fluoro-l-proline fails to detect peripheral tumors in humans. Nucl. Med. Biol. 35, 895-900. doi: 10.1016/j.nucmedbio.2008.08.003

Stryer, L. (1995). Biochemistry, 4th Edn. New York, NY: WH Freeman.

Suchorska, B., Tonn, J. C., and Jansen, N. L. (2014). PET imaging for brain tumor diagnostics. Curr. Opin. Neurol. 27, 683-688. doi: 10.1097/WCO.0000000000000143

Sutinen, E., Jyrkkio, S., Alanen, K., Nagren, K., and Minn, H. (2003). Uptake of [N-methyl-11C]alpha-methylaminoisobutyric acid in untreated head and neck cancer studied by PET. Eur. J. Nucl. Med. Mol. Imaging 30, 72-77. doi: 10.1007/s00259-002-1010-3

Tang, C., Xu, Z., Hu, K., Yao, B., Tang, G., and Nie, D. (2015). Radiation dosimetry estimation of $\mathrm{N}-(2-[(18) \mathrm{F}]$ fluoropropionyl)- L-glutamate based on the mice distribution data. Appl. Radiat. Isot. 98, 108-112. doi: 10.1016/j.apradiso.2015.01.026

Tang, G., Wang, M., Tang, X., Luo, L., and Gan, M. (2003). Synthesis and evaluation of O-(3-[18F]fluoropropyl)-L-tyrosine as an oncologic PET tracer. Nucl. Med. Biol. 30, 733-739. doi: 10.1016/S0969-8051(03)00097-0

Tani, H., Kurihara, H., Hiroi, K., Honda, N., Yoshimoto, M., Kono, Y., et al. (2014). Correlation of (18)F-BPA and (18)F-FDG uptake in head and neck cancers. Radiother. Oncol. 113, 193-197. doi: 10.1016/j.radonc.2014.11.001

Timmers, H. J., Carrasquillo, J. A., Whatley, M., Eisenhofer, G., Chen, C. C., Ling, A., et al. (2007). Usefulness of standardized uptake values for distinguishing adrenal glands with pheochromocytoma from normal adrenal glands by use of 6-18F-fluorodopamine PET. J. Nucl. Med. 48, 1940-1944. doi: 10.2967/jnumed.107.043281

Tomura, N., Mizuno, Y., and Saginoya, T. (2015). PET/CT findings for tumors in the base of the skull: comparison of 18 F-FDG with $11 \mathrm{C}$-methionine. Acta Radiol. 57, 325-332. doi: 10.1177/0284185115575342

Torrents, D., Estevez, R., Pineda, M., Fernandez, E., Lloberas, J., Shi, Y. B., et al. (1998). Identification and characterization of a membrane protein $(y+L$ amino acid transporter-1) that associates with $4 \mathrm{~F} 2 \mathrm{hc}$ to encode the amino acid transport activity $\mathrm{y}+\mathrm{L}$. A candidate gene for lysinuric protein intolerance. $J$. Biol. Chem. 273, 32437-32445. doi: 10.1074/jbc.273.49.32437

Toth, G., Lengyel, Z., Balkay, L., Salah, M. A., Tron, L., and Toth, C. (2005). Detection of prostate cancer with 11C-methionine positron emission tomography. J. Urol. 173, 66-69. discussion: 69. doi: 10.1097/01.ju.0000148326.71981.44

Toumpanakis, C., Kim, M. K., Rinke, A., Bergestuen, D. S., Thirlwell, C., Khan, M. S., et al. (2014). Combination of cross-sectional and molecular imaging studies in the localization of gastroenteropancreatic neuroendocrine tumors. Neuroendocrinology 99, 63-74. doi: 10.1159/000358727

Toyoda, M., Kaira, K., Ohshima, Y., Ishioka, N. S., Shino, M., Sakakura, K., et al. (2014). Prognostic significance of amino-acid transporter expression (LAT1, ASCT2, and xCT) in surgically resected tongue cancer. Br. J. Cancer 110, 2506-2513. doi: 10.1038/bjc.2014.178

Tredwell, M., Preshlock, S. M., Taylor, N. J., Gruber, S., Huiban, M., Passchier, J., et al. (2014). A general copper-mediated nucleophilic $18 \mathrm{~F}$ fluorination of arenes. Angew. Chem. Int. Ed. Engl. 53, 7751-7755. doi: 10.1002/anie. 201404436

Tsuyuguchi, N., Takami, T., Sunada, I., Iwai, Y., Yamanaka, K., Tanaka, K., et al. (2004). Methionine positron emission tomography for differentiation of recurrent brain tumor and radiation necrosis after stereotactic radiosurgery-in malignant glioma. Ann. Nucl. Med. 18, 291-296. doi: 10.1007/BF02984466

Utsunomiya-Tate, N., Endou, H., and Kanai, Y. (1996). Cloning and functional characterization of a system ASC-like $\mathrm{Na}$--dependent neutral amino acid transporter. J. Biol. Chem. 271, 14883-14890. doi: 10.1074/jbc.271.25.14883

Vaalburg, W., Coenen, H. H., Crouzel, C., Elsinga, P. H., Langstrom, B., Lemaire, C., et al. (1992). Amino acids for the measurement of protein synthesis in vivo by PET. Int. J. Rad. Appl. Instrum. B 19, 227-237. doi: 10.1016/0883-2897(92)90011-M

Van Laere, K., Ceyssens, S., Van Calenbergh, F., de Groot, T., Menten, J., Flamen, P., et al. (2005). Direct comparison of 18F-FDG and 11Cmethionine PET in suspected recurrence of glioma: sensitivity, inter-observer variability and prognostic value. Eur. J. Nucl. Med. Mol. Imaging 32, 39-51. doi: 10.1007/s00259-004-1564-3

Venneti, S., Dunphy, M. P., Zhang, H., Pitter, K. L., Zanzonico, P., Campos, C., et al. (2015). Glutamine-based PET imaging facilitates enhanced metabolic evaluation of gliomas in vivo. Sci. Transl. Med. 7:274ra217. doi: 10.1126/scitranslmed.aaa1009

Veronese, M., Schmidt, K. C., Smith, C. B., and Bertoldo, A. (2012). Use of spectral analysis with iterative filter for voxelwise determination of regional rates of cerebral protein synthesis with L-[1-11C]leucine PET. J. Cereb. Blood Flow Metab. 32, 1073-1085. doi: 10.1038/jcbfm.2012.27

Walter, F., Cloughesy, T., Walter, M. A., Lai, A., Nghiemphu, P., Wagle, N., et al. (2012). Impact of 3,4-dihydroxy-6-18F-fluoro-L-phenylalanine PET/CT on managing patients with brain tumors: the referring physician's perspective. J. Nucl. Med. 53, 393-398. doi: 10.2967/jnumed.111.095711

Wang, H. E., Liao, A. H., Deng, W. P., Chang, P. F., Chen, J. C., Chen, F. D., et al. (2004). Evaluation of 4-borono-2-18F-fluoro-L-phenylalanine-fructose as a probe for boron neutron capture therapy in a glioma-bearing rat model. $J$. Nucl. Med. 45, 302-308.

Wang, L., Lieberman, B. P., Ploessl, K., and Kung, H. F. (2014). Synthesis and evaluation of (1)(8)F labeled FET prodrugs for tumor imaging. Nucl. Med. Biol. 41, 58-67. doi: 10.1016/j.nucmedbio.2013.09.011

Washburn, L. C., Sun, T. T., Anon, J. B., and Hayes, R. L. (1978). Effect of structure on tumor specificity of alicyclic alpha-amino acids. Cancer Res. 38, 2271-2273.

Way, J. D., Wang, M., Hamann, I., Wuest, M., and Wuest, F. (2014). Synthesis and evaluation of 2-amino-5-(4-[(18)F]fluorophenyl)pent-4-ynoic acid ([(18)F]FPhPA): a novel (18)F-labeled amino acid for oncologic PET imaging. Nucl. Med. Biol. 41, 660-669. doi: 10.1016/j.nucmedbio.2014.05.140

Webster, J. M., Morton, C. A., Johnson, B. F., Yang, H., Rishel, M. J., Lee, B. D., et al. (2014). Functional imaging of oxidative stress with a novel PET imaging agent, 18F-5-fluoro-L-aminosuberic acid. J. Nucl. Med. 55, 657-664. doi: 10.2967/jnumed.113.126664

Weisbrod, A. B., Kitano, M., Gesuwan, K., Millo, C., Herscovitch, P., Nilubol, N., et al. (2012). Clinical utility of functional imaging with (1)(8)F-FDOPA in Von Hippel-Lindau syndrome. J. Clin. Endocrinol. Metab. 97, E613-E617. doi: 10.1210/jc.2011-2626 
Wong, K. K., Arabi, M., Zerizer, I., Al-Nahhas, A., Rubello, D., and Gross, M. D. (2011). Role of positron emission tomography/computed tomography in adrenal and neuroendocrine tumors: fluorodeoxyglucose and nonfluorodeoxyglucose tracers. Nucl. Med. Commun. 32, 764-781. doi: 10.1097/MNM.0b013e3283478a2a

Yin, J., Ren, W., Duan, J., Wu, L., Chen, S., Li, T., et al. (2014). Dietary arginine supplementation enhances intestinal expression of SLC7A7 and SLC7A1 and ameliorates growth depression in mycotoxinchallenged pigs. Amino Acids 46, 883-892. doi: 10.1007/s00726-0131643-5

Yoshimoto, M., Kurihara, H., Honda, N., Kawai, K., Ohe, K., Fujii, H., et al. (2013). Predominant contribution of L-type amino acid transporter to 4-borono-2(18)F-fluoro-phenylalanine uptake in human glioblastoma cells. Nucl. Med. Biol. 40, 625-629. doi: 10.1016/j.nucmedbio.2013.02.010
Zhao, C., Zhang, Y., and Wang, J. (2014). A meta-analysis on the diagnostic performance of (18)F-FDG and (11)C-methionine PET for differentiating brain tumors. AJNR Am. J. Neuroradiol. 35, 1058-1065. doi: 10.3174/ajnr.A3718

Conflict of Interest Statement: The authors declare that the research was conducted in the absence of any commercial or financial relationships that could be construed as a potential conflict of interest.

Copyright (c) 2018 Sun, Liu and Tang. This is an open-access article distributed under the terms of the Creative Commons Attribution License (CC BY). The use, distribution or reproduction in other forums is permitted, provided the original author(s) or licensor are credited and that the original publication in this journal is cited, in accordance with accepted academic practice. No use, distribution or reproduction is permitted which does not comply with these terms. 